\title{
Sesame Husk as Adsorbent for Copper(II) Ions Removal from Aqueous Solution
}

\author{
Haitham Ahmed El-Araby ${ }^{*}$, Abel Moneim Mohamed Ahmed Ibrahim², \\ Ahmed Hashem Mangood"1, Adel A.-H. Abdel-Rahman' ${ }^{1}$ \\ ${ }^{1}$ Chemistry Department, Faculty of Science, Menoufia University, Shebin El-Kom, Egypt \\ ${ }^{2}$ Chemistry Department, Faculty of Science, Alexandria University, Alexandria, Egypt \\ Email: ^haitham_elaraby@science.menofia.edu.eg
}

How to cite this paper: El-Araby, H.A., Ibrahim, A.M.M.A., Mangood, A.H. and Abdel-Rahman, A.A.-H. (2017) Sesame Husk as Adsorbent for Copper(II) Ions Removal from Aqueous Solution. Journal of Geoscience and Environment Protection, 5, 109-152.

https://doi.org/10.4236/gep.2017.57011

Received: May 28, 2017

Accepted: July 18, 2017

Published: July 21, 2017

Copyright $\odot 2017$ by authors and Scientific Research Publishing Inc. This work is licensed under the Creative Commons Attribution International License (CC BY 4.0).

http://creativecommons.org/licenses/by/4.0/

\begin{abstract}
In this study, the adsorption behavior of copper(II) ions from aqueous solutions onto sesame husk ( $\mathrm{SH}$ ) was investigated. The effect of different parameters such as $\mathrm{pH}$, contact time, adsorbent dosage, adsorbate concentration, temperature and agitation speed was studied. Thermodynamic parameters, equilibrium isotherms and kinetic data have been evaluated. The functional groups and surface morphology of SH adsorbent were characterized by FTIR and SEM. Adsorption equilibrium isotherms were expressed by Langmuir, Freundlich and Dubinin-Radushkevich (D-R) adsorption models and it was found that Langmuir adsorption model fits the experimental data better than Freundlich and D-R models. The adsorption can be best described by the pseudo second-order kinetic model.
\end{abstract}

\section{Keywords}

Copper(II) Ions Adsorption, Kinetics, Thermodynamic Parameters

\section{Introduction}

Serious environmental pollution arises as a result of the industrial activities and technology development due to waste streams of heavy metals from several industries which are poured into rivers. This occurs in many industries including mining process, smelting, metal plating, pigment, battery manufacturing processes, metallurgical industries [1] [2] [3], tannery and fabrication [4].

Various treatment methods and traditional technologies are used to remove heavy metals from wastewater, for instance, chemical oxidation/reduction [5] [6], electrodialysis [7], ultrafiltration [8] [9], solvent extraction [10], ion-exchange, evaporation, membrane filtration [11] [12] [13] [14], chemical precipitation [15], reverse osmosis [16] and coagulation [17]. However, there are some 
disadvantages accompany with these technologies such as high cost, sensitive operating conditions and possibility of secondary sludge production [18] [19] which suffocate their generalization in industries.

Adsorption is considered one of the important methods used for the removal of heavy metals [20] [21] [22] [23]. Comparing to the other purification and separation methods, adsorption-as a wastewater treatment process-has demonstrated its efficiency and economic feasibility and has gained importance in industrial applications [24] [25], as elimination of heavy metal cations from aqueous solution by selecting the suitable adsorbents under optimum operation conditions [26].

One of the advantages of natural adsorbents is that, they are easily applicable because of their adaption to several conditions as $\mathrm{pH}$, temperature, pressure and agitation. Besides, these materials are cheap and highly efficient [27]. So, development of alternative adsorbent materials featuring high availability, high adsorption capacities and feasibility is required [27]. In addition, the cost of these biosorbent materials is negligible compared with the cost of activated carbon or ion-exchange resins [28].

Recently, agricultural by-products have been widely studied for sequestering of metals from water including peat [29], wood [30], pine bark [31], banana pith [32], rice bran, soybean and cottonseed hulls [33], peanut shells [34], hazelnut shell [35], rice husk [36], sawdust [37], wool [38], orange peel and compost [39] and leaves [40]. Most of this work has approved that natural products could be perfect adsorbents for heavy metals [26].

Most metals in the fourth period of periodic table are carcinogenic. This carcinogenicity is assumed to be related to the electronic structure of transition and inner transitional metals [41]. Since copper is an essential metal in a number of enzymes for all forms of life, problems take place when it is deficient or in excess [26]. Copper is considered one of the most widely used heavy metal and the cupric ion, $\mathrm{Cu}(\mathrm{II})$, is the most prevalent species found in the environment and copper in this form is toxic to many living organisms [3] [42] [43].

Human is exposed to abnormally high levels of toxic metals in drink and food due to some practices such as cooking in copper-lined or copper-glazed pots and using copper pipes to supply water [44]. Drainage discharge, fertilizer industries, mining wastes, plating baths, paints and pigments, etc. are different sources of copper waste [12].

Although copper in trace amounts is essential to living organisms, excessive copper in water may cause harmful effects as neurotoxicity, jaundice, diarrhea, respiratory difficulties, liver and kidney failure, and even death [43] [45] [46]. Intake of excessively large portions of copper by man leads to severe mucosal irritation and corrosion, widespread capillary damage, hepatic and renal damage, central nervous system irritation followed by depression, gastrointestinal irritation [12] [47].

One of the epidemiological evidences, a high incidence of cancer among coppersmiths, suggests a primary carcinogenic role for copper [41]. The allowable 
limit of copper in drinking water is 1.3 and $2.0 \mathrm{mg} / \mathrm{L}$ according to U.S. Environmental Protection Agency (EPA) and WHO respectively [48].

Among the several methods described in literature, adsorption is the most effective method that has been successfully applied in the purification and recovery of $\mathrm{Cu}(\mathrm{II})$ ions from liquid waste because of its high efficiency and easy handling [49].

Agricultural materials especially those containing cellulose present potential metal biosorption capacity. Set of functional groups are exist in the basic components of the agricultural waste materials biomass such as extractives, hemicellulose, lignin, lipids, proteins, simple sugars, water hydrocarbons, starch. The functional groups facilitate metal complexation which helps for the heavy metals elimination [18] [50] [51] [52].

Agricultural waste materials seem to be viable option for heavy metal remediation for many reasons; 1) they are available in abundance, 2) are economic and ecofriendly, 3) more efficient, 4) they have unique chemical composition, 5) renewable and finally 6) low in cost. These materials are used in the removal of metal ions either in their natural form or after some physical or chemical modification [18].

For centuries, sesame seeds have been plowed particularly in Asia and Africa. In 2009, the world production of sesame seed was around 4 million tons and the major production areas were Asia (nearly 2.5 million tons) and Africa (nearly 1.3 million tons), with a reported percentage of $62.6 \%$ and $33.1 \%$ of the total world production [53]. Sesame seeds present a considerably higher content of polyphenolic compounds [54]. Husks are used as feed or fuel, but they have relatively high contents of phenolics in some cases, usually higher than their contents in seeds [55] and phenolic compounds can act as metal chelators [56]. Sćiban et al. [57] conducted an experiment on the efficiency of sawdust as an adsorbent in the removal of $\mathrm{Cu}(\mathrm{II})$ ion. It was found that, sawdust contains various organic compounds (lignin, cellulose and hemicellulose) with polyphenolic groups that could bind heavy metal ions through different mechanisms [58]. From all these literature review, it is expected that sesame husk (SH) could be used as a promising adsorbent for removal of copper(II) from simulated wastewater (aqueous solution).

In this article, sesame husk ( $\mathrm{SH}$ ) was prepared and used as a novel adsorbent for copper(II) removal from aqueous solution. The resulting $\mathrm{SH}$ was characterized by SEM and FT-IR. Also, adsorption isotherms and kinetics were investigated in order to evaluate the maximum adsorption capacity and the optimum adsorption conditions.

\section{Materials and Methods}

\subsection{Instrumentation}

Weighing was done using Mettler Toledo microbalance (with $0.1 \mathrm{mg}$ readability). The experimental values of $\mathrm{pH}$ were measured by $\mathrm{pH}$ Meter instrument model: Jenway 3510 (pH accuracy: $\pm 0.003 \%$, temperature resolution: $0.1^{\circ} \mathrm{C}$ and 
temperature accuracy: $\pm 0.5^{\circ} \mathrm{C}$ ). Before every measurement, the $\mathrm{pH}$ meter was calibrated with three standard buffer solutions ( $\mathrm{pH} 4.0, \mathrm{pH} 7.0$ and $\mathrm{pH} 10.0$ at $25^{\circ} \mathrm{C}$ ) supplied by Jenway. The adsorption experiments were carried out by mechanically shaking and BlueSpin Magnetic Hotplate Stirrer instrument model: BlueSpin MS7-H550-Pro was used (speed resolution: $\pm 1 \mathrm{rpm}$, control accuracy of work plate $\pm 1^{\circ} \mathrm{C}\left[<100^{\circ} \mathrm{C}\right]$ and the temperature is kept constant using external temperature sensor with accuracy of $\pm 0.2^{\circ} \mathrm{C}$ ). The adsorption experiments were performed in a batch system with a $100 \mathrm{~mL}$ stoppered pyrex glass flask. The $\mathrm{Cu}$ (II) solution was filtered through Whatman filter paper $(0.45 \mu \mathrm{m}$ pore size $)$ and heavy metal concentration of the initial and adsorbed solutions was measured by atomic absorption spectrometry (iCE 3300 AAS, Thermo Fisher Scientific Inc., UK) with air/acetylene flame. Quantification of the metals was based upon calibration curves of standard solutions of copper ion. Scanning electron microscopy (SEM), (JSM-5300, Jeol Ltd., Japan) was used to examine the surface morphology and to image the $\mathrm{SH}$ adsorbent before and after adsorption at a magnification of $2000 \times$ with an acceleration voltage of $20 \mathrm{kV}$. The Fourier transform-infrared spectroscopy (Spectrum BX FT-IR, PerkinElmer Inc., USA) study was conducted using a spectral frequency range of $4400-350 \mathrm{~cm}^{-1}$. Brunauer-Emmett-Teller (BET) surface area was determined using (Gas sorption analyzer, Quantachrome Ltd., UK). Elemental analysis (C, $\mathrm{H}$ and $\mathrm{N}$ ) was carried out using the Elemental Analyzer (EA 1108 CHNS-O, Fisons Ltd., UK).

\subsection{Sesame Husk Adsorbent}

The adsorbent used in the present study was sesame husk (SH) which is brought from local company for manufacturing of Tahini in Alexandria, Egypt after the stage of separating sesame from its husk using sesame dehulling water tank. Sesame husk ( $\mathrm{SH}$ ) was grinded using herb grinder (speed: 25,000 rpm) to increase the surface area until fine powder is gained and then was sieved through a range of sieves, and only the particles that passed through a $0.25 \mathrm{~mm}$ mesh were used in our study. The sieves were shaken for around $15 \mathrm{~min}$. After sieving, the separated particles of adsorbent was washed several times with Milli-Q water to remove any particles adhering to the surface and any water-soluble particles, then was oven-dried at $70^{\circ} \mathrm{C}$ for $2 \mathrm{~h}$ and the cycle of drying, cooling, dessicating and weighing was repeated until a constant weight is obtained. $\mathrm{SH}$ was chosen for the adsorption tests without any pre-treatment and was stored in dark polyester container for any further use. A summary of the properties of sesame husk adsorbent are listed in Table 1.

\subsection{Experimental Procedure}

Aqueous solutions of copper were prepared from copper sulphate pentahydrate $\left(\mathrm{CuSO}_{4} \cdot 5 \mathrm{H}_{2} \mathrm{O}\right)$ obtained from (Merck). Stock solutions of $1000 \mathrm{mg} / \mathrm{L}$ for $\mathrm{Cu}(\mathrm{II})$ were prepared, by dissolving desired amount of $\left(\mathrm{CuSO}_{4} \cdot 5 \mathrm{H}_{2} \mathrm{O}\right)$ in $500 \mathrm{~mL}$ of distilled water. After, different concentrations of solutions were prepared by appropriate dilution of the stock solution. Before mixing these solutions with the 
Table 1. Physico-chemical characterization of the sesame husk.

\begin{tabular}{|c|c|c|}
\hline \multicolumn{2}{|c|}{ Parameter } & Value \\
\hline \multicolumn{2}{|c|}{ Bulk density (g/L) } & 0.421 \\
\hline \multicolumn{2}{|c|}{ BET surface area $\left(\mathrm{m}^{2} / \mathrm{g}\right)$} & 0.656 \\
\hline \multicolumn{2}{|c|}{ Moisture content (\%) } & 2.23 \\
\hline \multicolumn{2}{|c|}{ Total loss of ignition (\%) } & 71.30 \\
\hline \multicolumn{2}{|c|}{$\mathrm{pH}$ ( $1 \%$ solution $)$} & 5.73 \\
\hline \multirow{3}{*}{ Elemental analysis } & Carbon content (\%) & 37.71 \\
\hline & Hydrogen content (\%) & 5.20 \\
\hline & Nitrogen content (\%) & 0.85 \\
\hline
\end{tabular}

adsorbent, test solutions with $\mathrm{pH}$ values ranging from 2 to 6 (to permit a determination of the optimum $\mathrm{pH}$ for adsorption) by dropwise addition of $0.1 \mathrm{~N}$ sodium hydroxide, $\mathrm{NaOH}(\mathrm{BDH})$ or $0.1 \mathrm{~N}$ hydrochloric acid, $\mathrm{HCl}(\mathrm{BDH})$. All the chemical compounds used to prepare the reagent solutions were of Analar grade. After selecting the optimal $\mathrm{pH}$, only one $\mathrm{pH}$ value was tested in all subsequent adsorption tests.

All the adsorption measurements were repeated three times to confirm reproducibility; hence, the reported value of metal ion adsorbed is the average of three measurements. Blanks containing no $\mathrm{Cu}$ (II) were used for each series of experiments. The adsorption capacity of $\mathrm{SH}$ was evaluated using the following expression [59]:

$$
q_{e}=\frac{\left(C_{o}-C_{e}\right) V}{W}
$$

where $q_{e}(\mathrm{mg} / \mathrm{g})$ is the adsorbed heavy metal (copper) amount per unit mass of the adsorbed sesame husk $(\mathrm{SH}), C_{o}(\mathrm{mg} / \mathrm{L})$ is the initial concentration of heavy metal solution and $C_{e}(\mathrm{mg} / \mathrm{L})$ is the concentration of the heavy metal in the aqueous phase at equilibrium, $V(\mathrm{~L})$ the volume of the aqueous phase and $W(\mathrm{~g})$ is the amount of $\mathrm{SH}$ adsorbent used.

The percent removal $(\% R)$ of $\mathrm{Cu}(\mathrm{II})$ ions was calculated by using following Equation [60]:

$$
\% R=\frac{\left(C_{o}-C_{t}\right)}{C_{o}} \times 100
$$

where $C_{o}$ and $C_{t}(\mathrm{mg} / \mathrm{L})$ are the $\mathrm{Cu}(\mathrm{II})$ initial concentration and the concentration at a given time $t$ (min.) respectively.

\section{Results and Discussion}

\subsection{Effect of $\mathrm{pH}$}

Varying the $\mathrm{pH}$ values is an important parameter in the adsorption process by influencing the surface charge of adsorbent, the degree of ionization and speciation of the adsorbate [13]. Therefore, studying the effect of $\mathrm{pH}$ on the removal 
efficiency of $\mathrm{Cu}$ (II) cations was performed by contacting $1.0 \mathrm{~g}$ of sesame husk adsorbent with $100 \mathrm{~mL}$ of $30 \mathrm{mg} / \mathrm{L}$ concentration of $\mathrm{Cu}(\mathrm{II})$ ion solution for 60 minutes with changing the solution $\mathrm{pH}$ range from 2 to 6 , at $298 \mathrm{~K}$ and the sample was stirred using a magnetic stirrer at agitation speed 300 round per minute (rpm). As displayed in Figure 1, there is a noticed severe increase in the copper removal at equilibrium from $58.02 \%$ to $95.13 \%$ occurred when the $\mathrm{pH}$ values of the solutions changed from 2 to 6 . Rising $\mathrm{pH}$ value above $\mathrm{pH} 6$ causes precipitation and hampers the adsorption where copper(II) ions will form the insoluble $\mathrm{Cu}(\mathrm{OH})_{2}$ precipitate [61] [62], so $\mathrm{pH} 6$ was chosen as optimum $\mathrm{pH}$ for $\mathrm{Cu}(\mathrm{II})$ adsorption. The decrease of removal efficiency at low $\mathrm{pH}$ is due to:

1) The existence of higher concentration of hydronium ions in the solution which compete with the $\mathrm{Cu}$ (II) ions for the binding sites of adsorbent [63].

2) At low $\mathrm{pH}$, the sesame husk surface is positively charged due to protonation which is obvious at low $\mathrm{pH}$ values due to the presence of high concentration of $\mathrm{H}^{+}$ions in the solution. Thereafter, electrostatic repulsion between the positively charged adsorbent surface and the metal ions in solution is engendered and the adsorption of $\mathrm{Cu}(\mathrm{II})$ becomes more unfavorable [64] [65].

3) The $\mathrm{Cl}^{-}$species in solution which come from adjusting the solution $\mathrm{pH}$ value using $\mathrm{HCl}$, lead to decreasing of the free $\mathrm{Cu}(\mathrm{II})$ ions and increasing in the formation of the chloro complex $\mathrm{CuCl}^{+}$. The molecular size of this complex is larger than that of the free $\mathrm{Cu}(\mathrm{II})$ and is affect inversely on the adsorption, resulting decrease in copper uptake but this effect is very limited [13].

However, Increasing the $\mathrm{pH}$ leads to diminishing the hydronium ion concentration, the adsorbent surface became deprotonated and subsequently, increasing of $\mathrm{Cu}$ (II) uptake [66].

Pandey et al. [67] studied the effect of Zeolite $\mathrm{NaX}$ as an adsorbent on removal of $\mathrm{Cu}(\mathrm{II})$ ions from aqueous stream and it was found that uptake capacity of

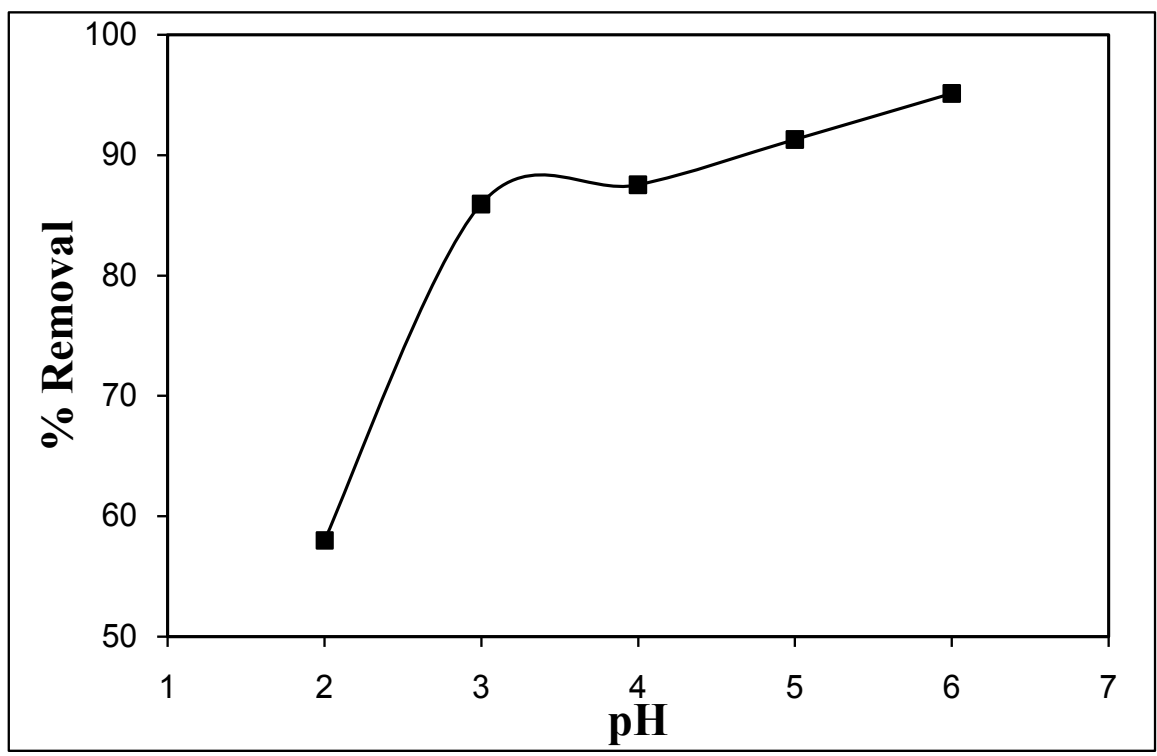

Figure 1. Effect of $\mathrm{pH}$ on the \% removal of $\mathrm{Cu}(\mathrm{II})$ ions onto sesame husk ( T: $298 \mathrm{~K}, 300$ $\mathrm{rpm}, C_{o}: 30 \mathrm{mg} / \mathrm{L}$ and $1.0 \mathrm{~g}$ of adsorbent). 
copper(II) ions was maximum at $\mathrm{pH}$ 6. The same results were observed by Hossain et al. [61] and Oo et al. [62].

\subsection{Effect of Contact Time}

One of the most critical parameters for successful adsorption process is determining the percentage removal of metal ions by changing the contact time of the aqueous solution with the adsorbent. To study the effect of contact time, the experiment conducted with initial copper concentration $\left(C_{o}: 30 \mathrm{mg} / \mathrm{L}\right)$ at optimum $\mathrm{pH}$ 6, with a dose of $1.0 \mathrm{~g}$ of SH/100 ml Cu(II) solution at $298 \mathrm{~K}$ and rotation speed of $300 \mathrm{rpm}$ with contact time of 1, 3, 5, 7, 10, 15, 20, 30, 45 and $60 \mathrm{mi}-$ nutes. The effect of contact time on the percentage of $\mathrm{Cu}$ (II) elimination by $\mathrm{SH}$ adsorbent is shown in Figure 2. A two-stage manner was observed: firstly a highly fast stage, followed by a second slow stage of adsorption. The initial increase in the percentage adsorption of metal ions is attributed to existence of a large number of active sites on the SH surface that were swiftly occupied by a significant amount of copper ions. The second stage of low sorption rate until saturation process occurred due to two reasons: 1) the adsorbent pores become saturated at the initial stage of adsorption where the metal ions are adsorbed. Thus, a few numbers of ions are attached on the surface due to slower diffusion of solute into the interior of the adsorbent [68],2) The binding sites were shortly become limited and the remaining unoccupied surface sites are hard to be occupied by copper ions due to the arising of repulsive forces between the copper on the solid surface and the residual copper in the liquid phase [69] [70] [71]. Only 10 - 15 minutes equilibration period was needed for SH adsorbent to achieve equilibrium; no considerable further metal adsorption was noticed up to $60 \mathrm{mi}$ nutes (Figure 2). However, a contact time of $30 \mathrm{~min}$ was set for the subsequent batch experiments. The elimination percentage of copper ions onto $\mathrm{SH}$ reached

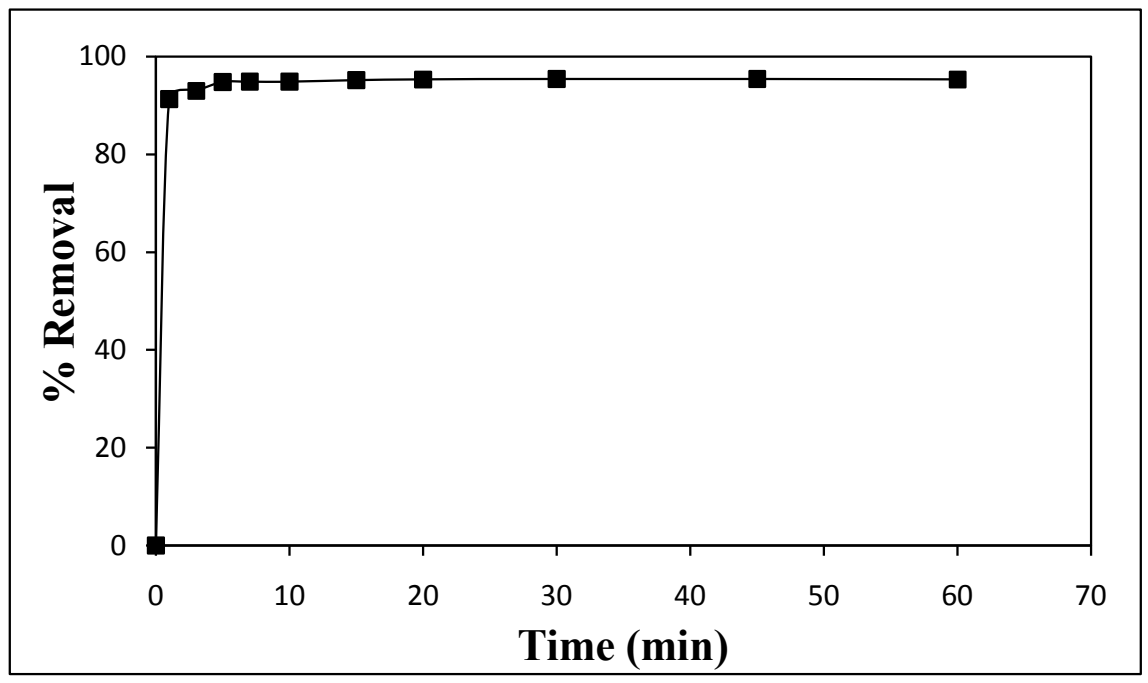

Figure 2. Effect of contact time on the $\mathrm{Cu}(\mathrm{II})$ ions removal efficiency onto sesame husk at different initial concentrations (T: $298 \mathrm{~K}, 300 \mathrm{rpm}, \mathrm{pH}$ : 6 and $1.0 \mathrm{~g}$ of adsorbent for 60 $\min )$. 
95.13\% after 15 minutes of contact time. The lower contact time to reach equilibrium observed in this study indicates that the adsorption process is quite fast.

\subsection{Effect of Adsorbent Dosage}

The effect of adsorbent dosage on $\mathrm{Cu}$ (II) ions percentage removal and adsorption capacity was investigated using different doses: $0.2,0.4,0.6,0.8,1.0,1.2$ and $1.4 \mathrm{~g}$ in $100 \mathrm{~mL}$ of $30 \mathrm{mg} / \mathrm{L} \mathrm{Cu}$ (II) by keeping other variables constant (at optimal pH of 6, temperature: $298 \mathrm{~K}$, agitation speed: $300 \mathrm{rpm}$, contact time: 30 min. and $C_{o}: 30 \mathrm{mg} / \mathrm{L}$ ) as shown in Figure 3. Results show that with the increase in adsorbent dose from 0.2 to $1.0 \mathrm{~g}$, the percentage removal of copper ions rose from $63.50 \%$ to $95.13 \%$ then it decreases to be $90.27 \%$ with the consequence increase in dose up to $1.4 \mathrm{~g}$ respectively. This rising in the heavy metal percentage removal with increasing the adsorbent dosage is plausible because of the increase in adsorbent surface area and the availability of more exchangeable binding sites on the surface which are ready for metal ion uptake [72] [73] [74] [75] [76]. Decreasing the adsorption efficiency with further increase in dose above $1.0 \mathrm{~g}$ could be interpreted as a result of a partial overlapping or aggregation of adsorbent active sites as a result of overcrowding of adsorbent particles [77] [78] [79], which results in interaction of active site with adsorbent atoms rather than adsorbate and thus, the total adsorption area decreases [80] [81].

However, the copper(II) ions uptake capacity or amount of metal adsorbed ( $q$, $\mathrm{mg} / \mathrm{g}$ ) decreases gradually upon increasing the dosage as shown in Figure 3. Adsorption capacity decreased from $8.839 \mathrm{mg} / \mathrm{g}$ at $0.2 \mathrm{~g}$ to $1.940 \mathrm{mg} / \mathrm{g}$ at $1.4 \mathrm{~g}$. This occurs due to the fact that some adsorbent active sites stay unsaturated during the adsorption process. Hence, the number of unsaturated active sites available for sorption increases with increasing the adsorbent dose which can be ascribed to an insufficiency of metal ions in solution compared to the available

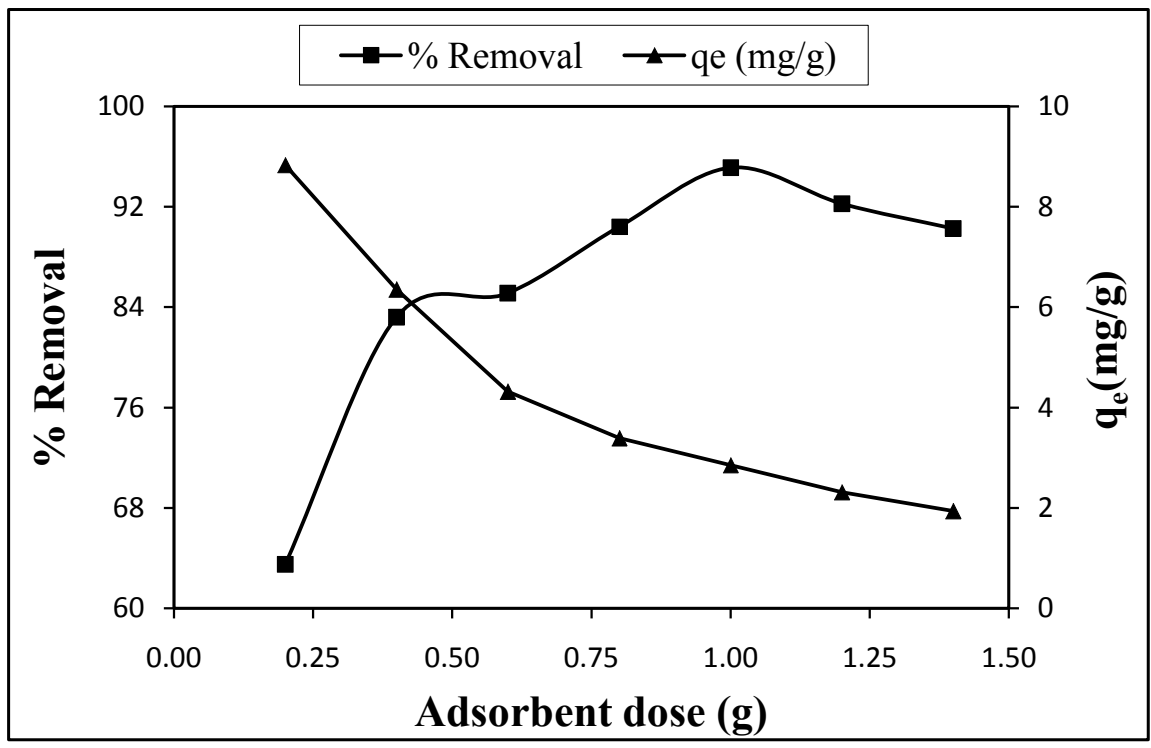

Figure 3. Effect of sesame husk dose on the \% removal and adsorption capacity at equilibrium of $\mathrm{Cu}(\mathrm{II})$ ions ( T: $298 \mathrm{~K}, 300 \mathrm{rpm}, \mathrm{pH}: 6$ and $C_{\circ}: 30 \mathrm{mg} / \mathrm{L}$ for $30 \mathrm{~min}$ ). 
binding sites [82] [83] [84] [85]. Also, the decrease of $q_{e}$ with increasing the sorbent mass is attributed the decrease of the adsorbent total surface area and the increase in diffusion path length due to aggregation of adsorbent particles [86] [87] [88]. Furthermore upon increasing the adsorbent dosage, the binding sites of the adsorbent are shielded from metal where elevated dosage could impose a screening effect of the dense outer layer of the cells [89] [90].

\subsection{Effect of Adsorbate Concentration}

The experiment was carried out with variable initial copper ion concentrations $(30,40,50,70$ and $100 \mathrm{mg} / \mathrm{L})$ and constant temperature (298 K), pH (6.0), contact time (30 min.), adsorbent dosage ( $0.2 \mathrm{~g}$ ) and shaking speed ( $300 \mathrm{rpm})$. It can be observed that the copper(II) ions removal rate decreases with the increase of the initial concentration. The percent adsorption (\%) is given in Figure 4(a) which shows that the percentage of $\mathrm{Cu}$ sorption on sesame husk decreased from $62.53 \%$ to $21.01 \%$ as the initial $\mathrm{Cu}$ (II) concentration increased from $30 \mathrm{mg} / \mathrm{L}$ to $100 \mathrm{mg} / \mathrm{L}$ respectively. This is because at low concentration the sorbent have enough active sites which could be easily occupied by metal ions since the ratio of available adsorption binding sites to the initial number of $\mathrm{Cu}(\mathrm{II})$ metal ions is large. Whereas at higher concentration, there is no more active sites to be occupied and the ratio of available adsorption active sites become fewer. That's why; $\mathrm{Cu}$ ions are left unadsorbed in solution and the percentage removal of $\mathrm{Cu}$ (II) ions which depends upon the initial concentration, decreases [91]. This result is found matching with recent studies by Bhatti et al. [92], Azouaou et al. [93] and Yao et al. [94] where the percent of metal adsorption decreases with increasing the concentration of adsorbate.

As seen in Figure 4(b), the adsorbed amount of metal ions per unit mass of adsorbent $\left(q_{e}\right)$ increases as the initial concentration of the adsorbate solution increases until it reaches maximum then decreases where $q_{e}$ increased from 8.704 $\mathrm{mg} / \mathrm{g}$ at $\mathrm{Cu}(\mathrm{II})$ ions concentration of $30 \mathrm{mg} / \mathrm{L}$ to be highest value of $12.94 \mathrm{mg} / \mathrm{g}$ at $70 \mathrm{mg} / \mathrm{L}$ of $\mathrm{Cu}$ (II) followed by decreasing to be $10.35 \mathrm{mg} / \mathrm{g}$ at $100 \mathrm{mg} / \mathrm{L}$. This can be interpreted as following; the increasing in $q_{e}$ value from initial concentration of $30 \mathrm{mg} / \mathrm{L}$ to $70 \mathrm{mg} / \mathrm{L}$ took place for two reasons: 1) with a solution of low concentration, the ratio between the number of metal ions to the number of available adsorption sites is small and subsequently the fractional adsorption becomes independent on initial concentration. However, at high concentration the available sites of adsorption becomes fewer and hence the adsorption of metal ions is dependent upon initial concentration. Thus, increasing the initial concentration of copper metal solution causes further increasing in $q_{e}$ value [88] [95]. 2) Higher concentration gradient can act as a driving force to overcome resistance to mass transfer of metal ions between the aqueous phase and the solid phase resulting in higher probability of collision between $\mathrm{Cu}(\mathrm{II})$ ions and the active sites [96] [97]. However, further increasing of the copper ions concentration from $70 \mathrm{mg} / \mathrm{L}$ to $100 \mathrm{mg} / \mathrm{L}$ leads to decreasing in $q_{e}$ value as observed where at a high certain concentration $(70 \mathrm{mg} / \mathrm{L})$, the active adsorption sites became saturated [93] [98]; after which, $q_{e}$ decreases. 


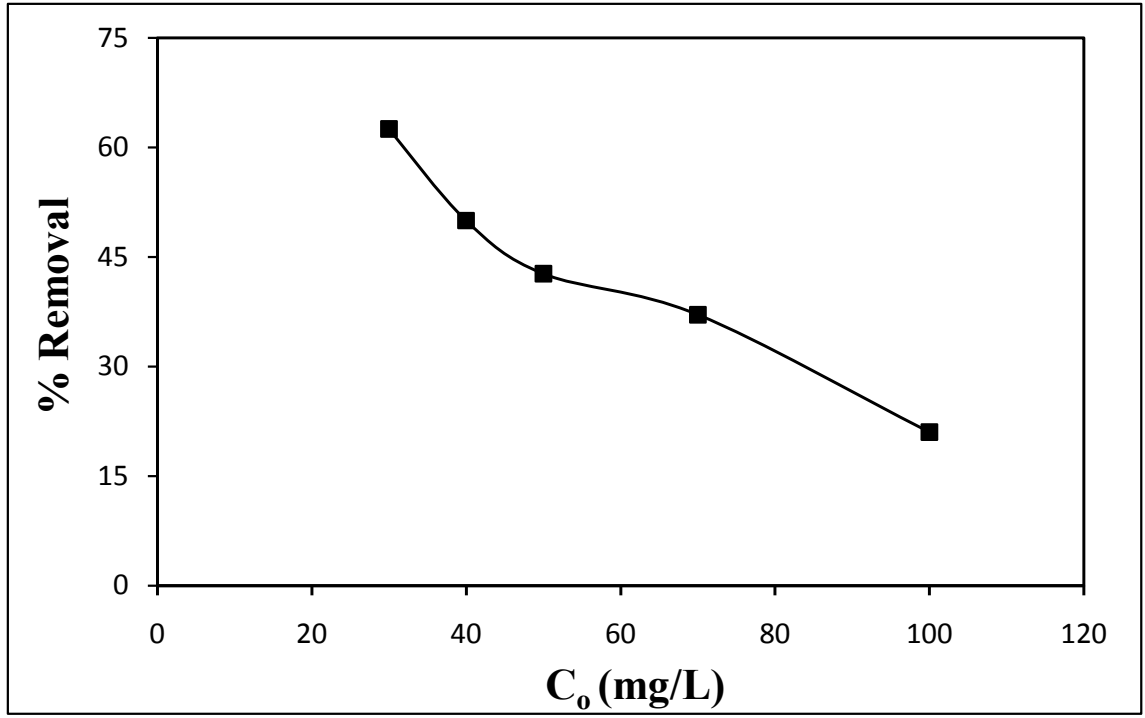

(a)

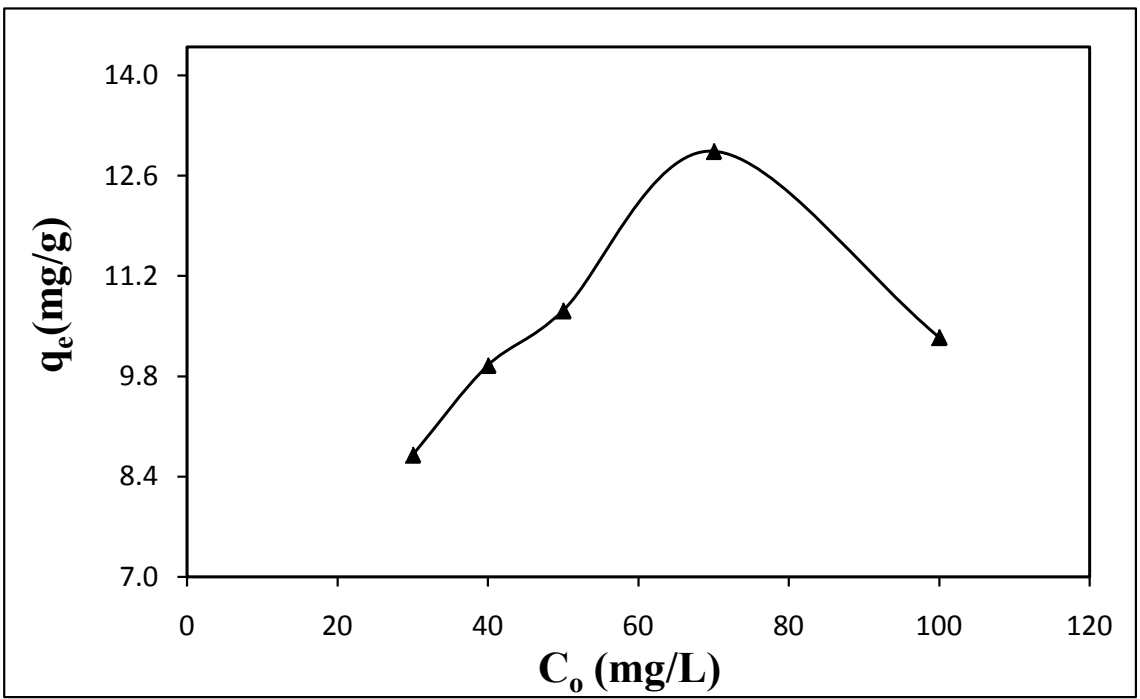

(b)

Figure 4. (a) Effect of initial concentration on the \% removal of $\mathrm{Cu}$ (II) ions onto sesame husk ( T: $298 \mathrm{~K}, 300 \mathrm{rpm}, \mathrm{pH}: 6$ and $0.2 \mathrm{~g}$ of adsorbent for $30 \mathrm{~min}$ ). (b) Effect of initial concentration on the adsorption capacity at equilibrium of $\mathrm{Cu}$ (II) ions onto sesame husk ( $T: 298 \mathrm{~K}, 300 \mathrm{rpm}, \mathrm{pH}: 6$ and $0.2 \mathrm{~g}$ of adsorbent for $30 \mathrm{~min}$ ).

Zhang and Wang [99] studied the effect of the initial concentration of $\mathrm{Ni}$ (II) ions on the adsorption capacity $\left(q_{e}\right)$ of lignocellulose/montmorillonite nanocomposite and the trend obtained of adsorption capacity was the same as the current study. $q_{e}$ first increased with increasing initial Ni(II) concentration until it reached maximum at $0.0032 \mathrm{~mol} / \mathrm{L}$ then decreased until $0.0036 \mathrm{~mol} / \mathrm{L}$.

Similarly, Ang et al. [100] determined the copper(II) adsorption effect by the neem leaf powder (NLP). Results showed that the adsorption capacity is increased with increasing the initial copper(II) ions concentration until it reaches maximum then decreased due to saturation of active groups. This is complied with the results obtained from the present study. 


\subsection{Effect of Temperature}

The adsorption of $\mathrm{Cu}(\mathrm{II})$ ions on sesame husk ( $\mathrm{SH})$ was examined for the initial solution concentration of $30 \mathrm{mg} / \mathrm{L}$ at 298, 303, 308 and $313 \mathrm{~K}$. As presented in Figure 5(a) and Figure 5(b), upon rising the temperature from 298 to $313 \mathrm{~K}$, the adsorption removal percentage decreased from $95.33 \%$ to $83.13 \%$ respectively. In the same manner, adsorption capacity of copper(II) metal ions onto SH decreased from $2.862 \mathrm{mg} / \mathrm{g}$ at $298 \mathrm{~K}$ to be $2.508 \mathrm{mg} / \mathrm{g}$ at $313 \mathrm{~K}$. When the temperature is increased, degradation of the adsorbent and alteration of active functional groups take place which will vary the surface chemistry of sorbent and the

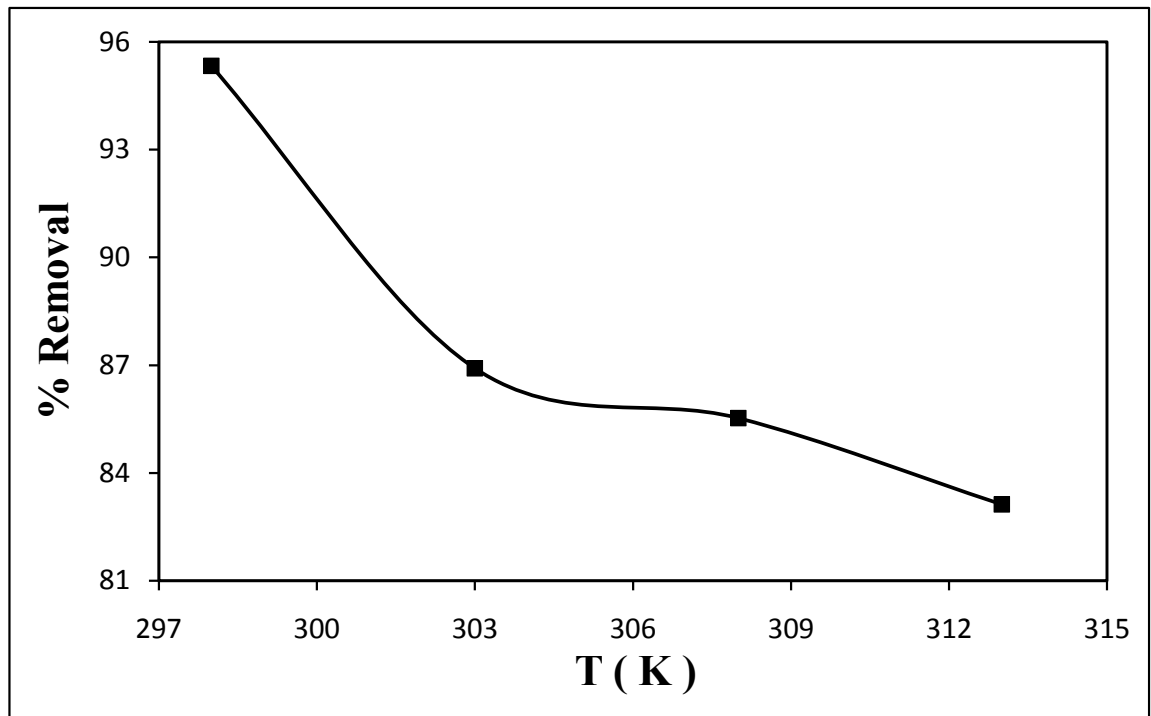

(a)

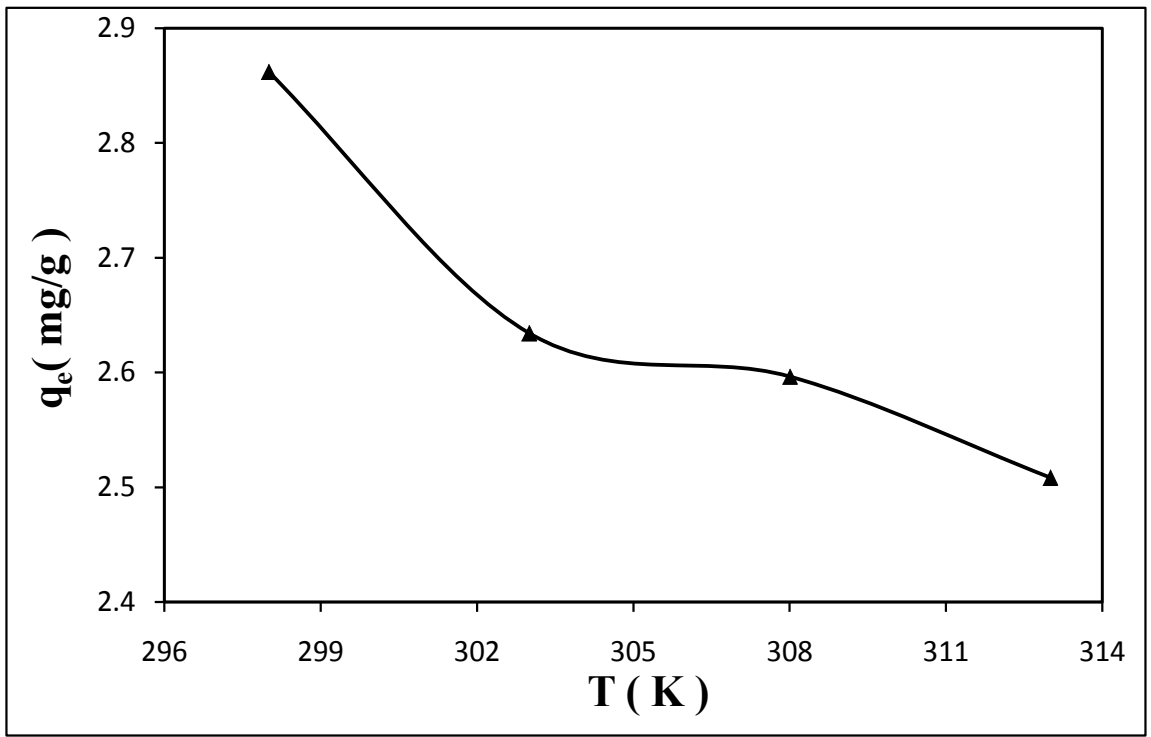

(b)

Figure 5. (a) Effect of temperature on the \% removal of $\mathrm{Cu}$ (II) ions onto sesame husk (300 rpm, pH: 6, $C_{o}: 30 \mathrm{mg} / \mathrm{L}$ and $1.0 \mathrm{~g}$ of adsorbent for $30 \mathrm{~min}$ ). (b) Effect of temperature on the adsorption capacity at equilibrium of $\mathrm{Cu}(\mathrm{II})$ ions onto sesame husk (300 rpm, $\mathrm{pH}$ : 6, $C_{o}: 30 \mathrm{mg} / \mathrm{L}$ and $1.0 \mathrm{~g}$ of adsorbent for $30 \mathrm{~min}$ ). 
number of active functional groups available for adsorption of heavy metal ions decreases. Besides, bonds are ruptured at higher temperature so desorption is favored [100]. Additionally on increasing the temperature, the thickness of the boundary layer decreases because the metal ions tend increasingly to flee from the biomass surface to the solution phase which limits the adsorption capacity [101] [102]. Moreover, at higher temperatures the surface activity of the biomass decreases [103] [104], even there is a possibility of damaging the surface active sites which reduces the sorption ability of the materials [105]. Eventually, the loss in the adsorption capacity is caused by the change in the texture of the sorbent and as a result of the material deterioration [106].

Alpat et al. [107] studied the effect of temperature on the biosorption capacity $\left(q_{t}\right)$ of $\mathrm{Ni}(\mathrm{II})$ on Circinella sp. and found that the increase in temperatures from $40^{\circ} \mathrm{C}$ to $60^{\circ} \mathrm{C}$ decreases the $q_{t}$ value. This decrease was ascribed to that, the biosorbent surface has been deactivated or some of biosorbent's active sites were destroyed.

Similar results were obtained by Aksu and İşoğlu [108] who reported that the equilibrium uptake capacity of copper(II) ions using dried sugar beet pulp of sorbent decreased from 24.6 to $12.3 \mathrm{mg} / \mathrm{g}$ with increasing temperature from 25 to $45^{\circ} \mathrm{C}$.

\subsection{Effect of Agitation Speed}

The effect of agitation speed on adsorption of copper was studied over the range 100 - $500 \mathrm{rpm}$ for 30 minutes with $100 \mathrm{ml}$ solution containing $30 \mathrm{mg} / \mathrm{L}$ copper metal ions and $1.0 \mathrm{~g}$ of sesame husk. Figure 6 refers that the percent removal of adsorption increased from 87.81 to be maximum of $95.33 \%$ upon increasing the agitation speed from $100 \mathrm{rpm}$ to $300 \mathrm{rpm}$. This agitation speed $(300 \mathrm{rpm})$ was

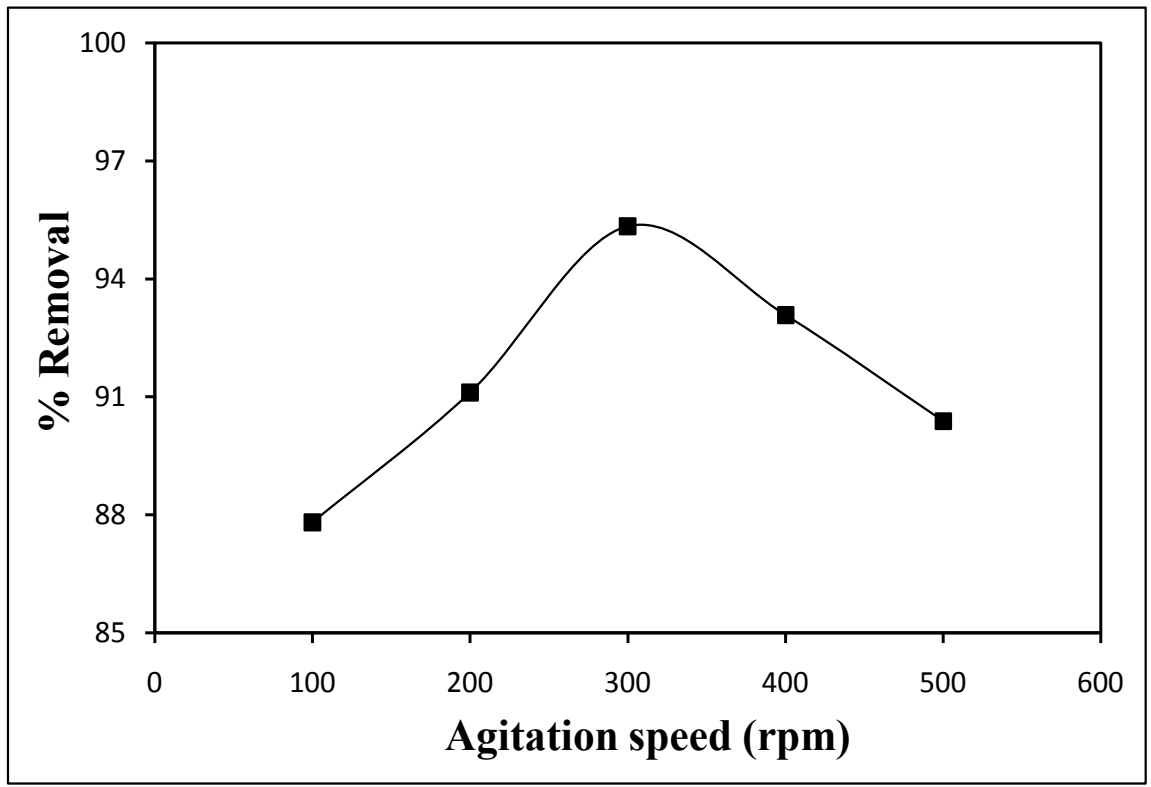

Figure 6. Effect of agitation speed on the \% removal of $\mathrm{Cu}(\mathrm{II})$ ions onto sesame husk ( $T$ : $298 \mathrm{~K}, \mathrm{pH}: 6, C_{o}: 30 \mathrm{mg} / \mathrm{L}$ and $1.0 \mathrm{~g}$ of adsorbent for $30 \mathrm{~min}$.). 
chosen as an optimum speed to be applied for other experiments. The Low speed cannot distribute the particles properly in the metal solution but accumulated [71]. This will bury some of the binding active sites of the adsorbent layer and not all of the adsorbent active sites can adsorb the metal ions. That's why, the agitation rate should be sufficient enough to assure that all the surface binding sites are already available for metal uptake [109]. However, increasing the agitation speed beyond $300 \mathrm{rpm}$ will affect negatively on the $\mathrm{Cu}$ (II) ions percent removal where it decreased from $95.33 \%$ at $300 \mathrm{rpm}$ to $90.39 \%$ at $500 \mathrm{rpm}$. This is attributed to an increase in desorption tendency of adsorbate ions [109]. In addition, the high speed spreads vigorously the adsorbent particles in the solution and does not permit a sufficient time for adsorbent to bind with copper ions [110].

\subsection{Thermodynamic Parameters}

There is a possibility to determine the thermodynamic parameters for the adsorption reaction by considering the equilibrium constants under the several experimental conditions. These parameters could be calculated by the following Van't Hoff equation [109] [111] [112]:

$$
\ln K_{C}=\frac{\Delta S^{\circ}}{R}-\frac{\Delta H^{\circ}}{R T}
$$

where $R$ is universal gas constant $(8.314 \mathrm{~J} /(\mathrm{mol} \cdot \mathrm{K})), T(\mathrm{~K})$ is the absolute temperature in kelvin and $K_{c}$ is the linear adsorption distribution coefficient defined as: $K_{c}=C_{o} / C_{e}$ in which $C_{o}$ and $C_{e}(\mathrm{mg} / \mathrm{L})$ are the initial adsorbate concentrations and adsorbate concentrations remained in the liquid phase at equilibrium respectively, $\Delta G^{o}$ is the free energy of adsorption, $\Delta H^{\circ}(\mathrm{kJ} / \mathrm{mol})$ is the enthalpy change and $\Delta S^{\circ}(\mathrm{J} /(\mathrm{mol} \cdot \mathrm{K}))$ is the entropy change.

By plotting a graph between $\ln K_{c}$ and $1 / T$ as shown in Figure 7, a straight line

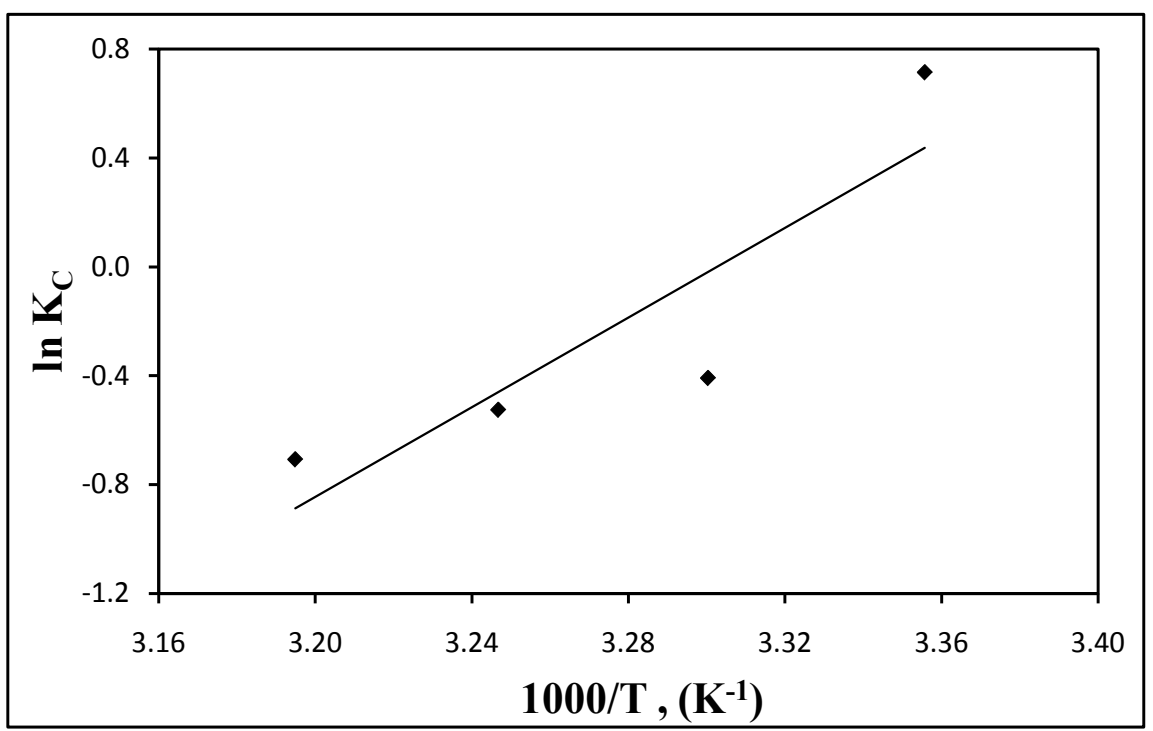

Figure 7. Effect of temperature on the thermodynamic behavior of adsorption of $\mathrm{Cu}$ (II) ions onto sesame husk ( $300 \mathrm{rpm}, \mathrm{pH}: 6, C_{o}: 30 \mathrm{mg} / \mathrm{L}$ and $1.0 \mathrm{~g}$ of adsorbent for $30 \mathrm{~min}$ ). 
is obtained from which $\Delta H^{\circ}$ and $\Delta S^{\circ}$ values were estimated from slope and intercept respectively.

There is a direct relation between the change in Gibbs free energy upon adsorption $\Delta G^{\circ}(\mathrm{kJ} / \mathrm{mol})$ and both of the entropy change $(\Delta S)$ and heat of adsorption $\left(\Delta H^{\circ}\right)$ which can be calculated by the equation [13]:

$$
\Delta G^{\circ}=\Delta H^{\circ}-T \cdot \Delta S^{\circ}
$$

The thermodynamic parameters are displayed in Table 2. The negative value of $\Delta H^{\circ}$ implies that the adsorption phenomenon is exothermic in nature. The sign of $\Delta S^{o}$ indicates whether the adsorption reaction is an associative or dissociative mechanism. As shown in Table 2, since $\Delta S^{\circ}$ has a negative value so an associative mechanism is involved during the adsorption process. Adsorption leads to order through the formation of an activated complex between adsorbate and adsorbent [109]. Also, $\Delta S^{\circ}$ sign plays an important role in reflecting whether the order of the adsorbate at the solid/solution interface during the adsorption process becomes less random $\left(\Delta S^{\circ}<0\right)$ or more random $\left(\Delta S^{\circ}>0\right)$ [113]. Moreover, negative $\Delta S^{\circ}$ value involves decreasing in the degree of freedom of $\mathrm{Cu}$ (II) ions in the solution.

The negative values of $\Delta G^{o}$ indicate that the adsorption process is spontaneous However, the $\Delta G^{\circ}$ value changed from negative to positive value on increasing the temperature which means that the adsorption reaction is non-feasible and non-spontaneous at higher temperature indicating that the spontaneous nature of adsorption is inversely proportional to the temperature [114].

\subsection{Characterization of Sesame Husk}

\subsubsection{Fourier Transform-Infrared Spectroscopic Analysis (FT-IR)}

Examination the characteristic functional groups that makes the adsorption possible was done by Fourier Transform-Infrared Spectroscopic Analysis (FTIR). The FT-IR spectra of sesame husk before and after adsorption of $\mathrm{Cu}$ (II) ions are shown in Figure 8. Different types of functional groups were detected in the adsorbent where the infrared spectrum displayed a large number of adsorption peaks.

The broad band peak at $3455.00 \mathrm{~cm}^{-1}$ was assigned to the stretching vibration of hydroxyl groups $(\mathrm{O}-\mathrm{H})$ of hydrogen bonded alcohols, phenols on the surface of sesame husk [115] [116] and - NH stretching [84] [117] but after adsorption it was slightly shifted to higher frequency at $3455.60 \mathrm{~cm}^{-1}$. The peaks at 2926.62 and $2856.38 \mathrm{~cm}^{-1}$ were due to the stretching vibration of $\mathrm{CH}_{3}$ and $\mathrm{CH}_{2}$ groups

Table 2. Thermodynamic parameters for the adsorption of $\mathrm{Cu}$ (II) onto sesame husk.

\begin{tabular}{cccc}
\hline$T(\mathrm{~K})$ & $\Delta G^{o}(\mathrm{~kJ} / \mathrm{mol})$ & $\Delta H^{o}(\mathrm{~kJ} / \mathrm{mol})$ & $\Delta S^{o}(\mathrm{~J} / \mathrm{mol} \cdot \mathrm{K})$ \\
\hline 298 & -1.085 & & \\
303 & 0.046 & -68.48 & -226.15 \\
308 & 1.177 & & \\
313 & 2.308 & & \\
\hline
\end{tabular}




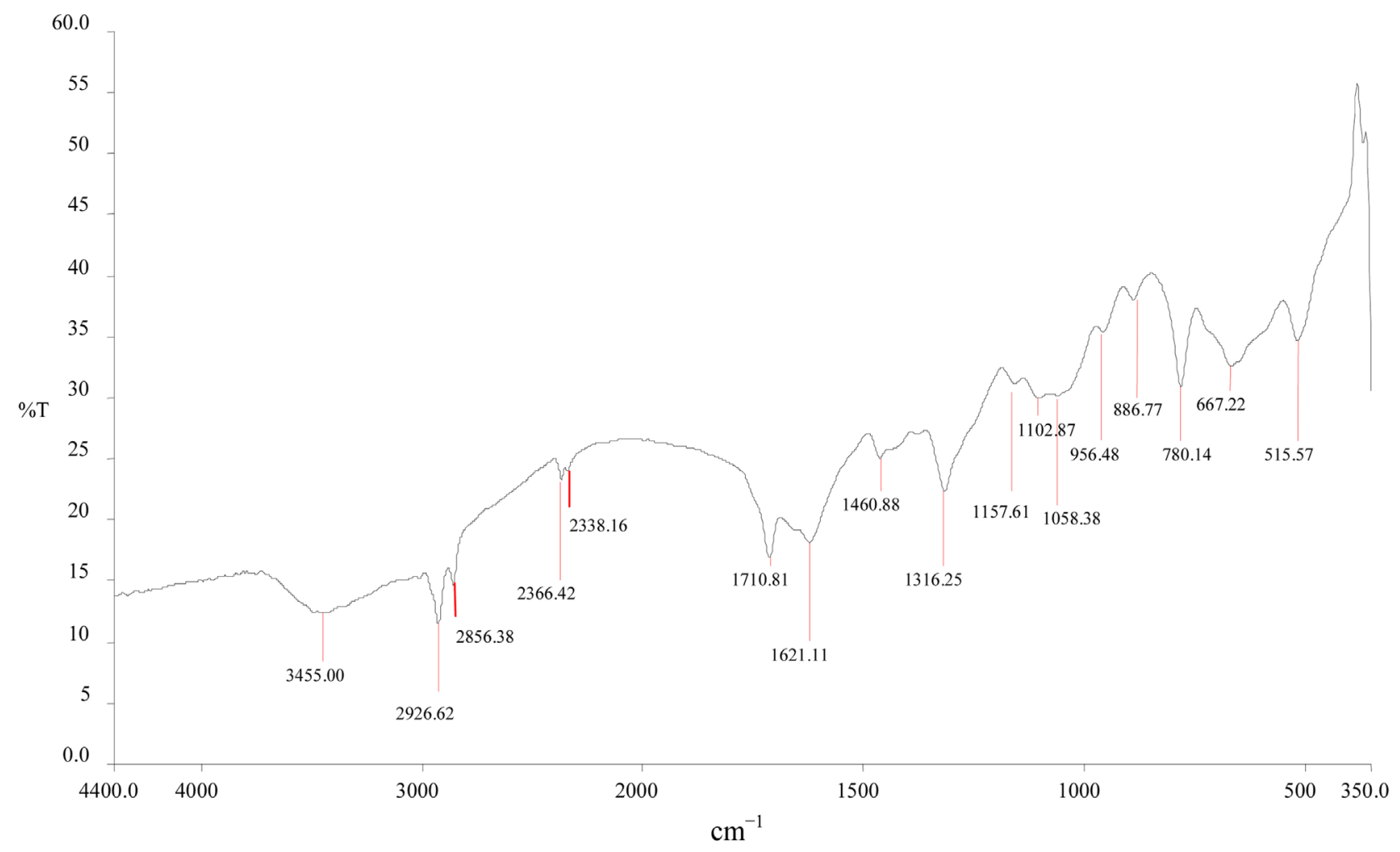

(a)

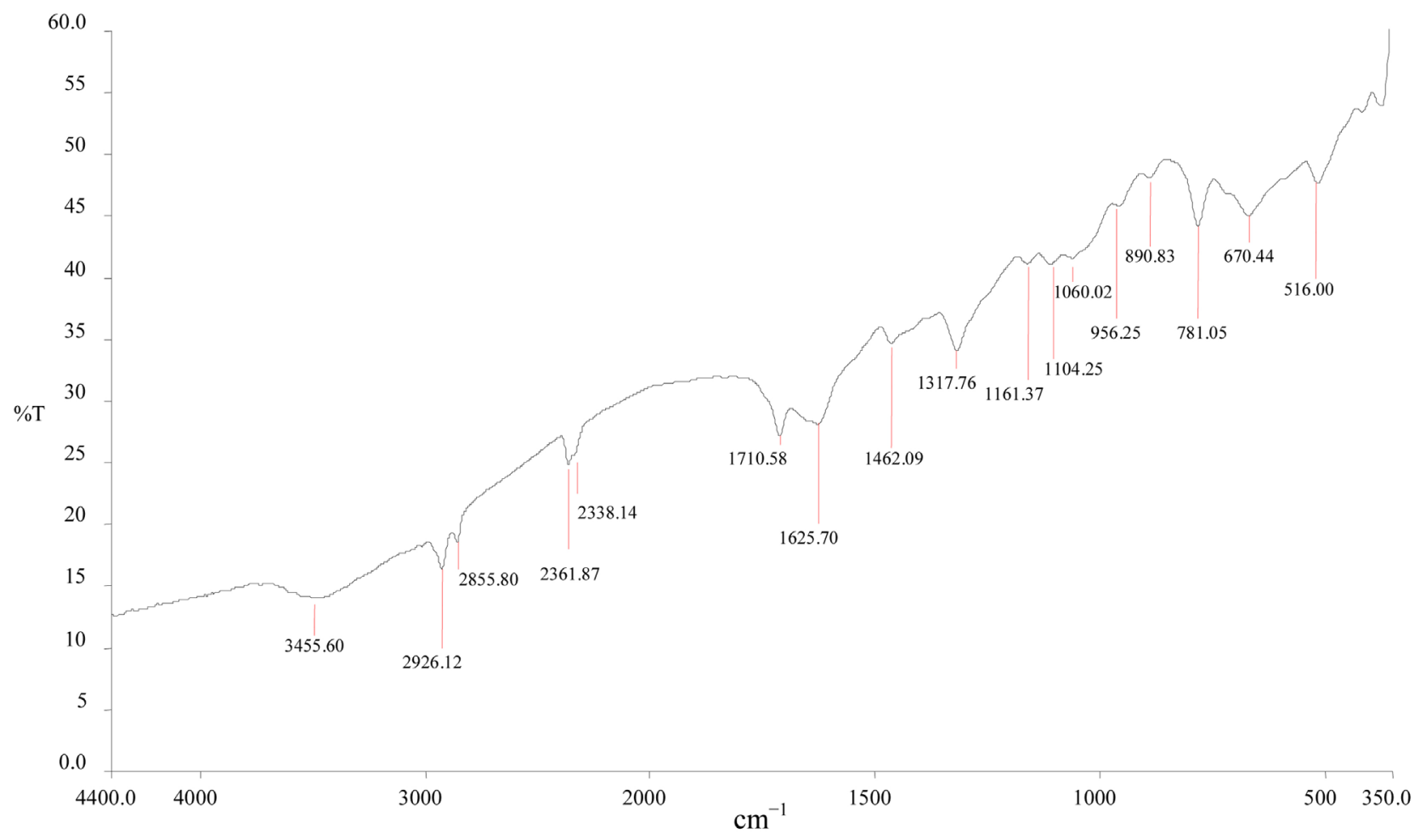

(b)

Figure 8. FTIR Spectra of sesame husk (a) before adsorption and (b) after adsorption of $\mathrm{Cu}(\mathrm{II})$ ions.

respectively [118] and these bands were changed to 2926.12 and $2855.80 \mathrm{~cm}^{-1}$ correspondingly. The two distinctive bands at 2366.42 and $2338.16 \mathrm{~cm}^{-1}$ are 
from the carbon dioxide $\left(\mathrm{CO}_{2}\right)$ in air, they were shifted to 2361.87 and 2338.14 $\mathrm{cm}^{-1}$ respectively [119] [120]. The strong band that appeared at $1710.81 \mathrm{~cm}^{-1}$ is corresponding to the stretching $\mathrm{C}=\mathrm{O}$ of ketone [121] [122] [123] and its intensity was decreased a bit to be $1710.58 \mathrm{~cm}^{-1}$. The band at $1621.11 \mathrm{~cm}^{-1}$ could be attributed to stretching vibration of $\mathrm{CO}$ from carboxylic acid in the presence of intermolecular hydrogen bonding [124]. The band at $1460.88 \mathrm{~cm}^{-1}$ is characteristic to the scissoring vibrations of $-\mathrm{CH}_{2}$ functional groups in lipids [125] [126] [127]. The band at $1316.25 \mathrm{~cm}^{-1}$ is ascribed to $-\mathrm{CH}_{2}$ wagging vibration in cellulose and hemicelluloses [128]. The band at $1157.61 \mathrm{~cm}^{-1}$ can be ascribed to the vibration of C-O-C in polysaccharides (cellulose and hemicelluloses) [129] [130] [131] [132]. The band at $1102.87 \mathrm{~cm}^{-1}$ can be indicative of $\mathrm{O}-\mathrm{H}$ associated with cellulose and hemicelluloses [133] [134]. The peak at $1058.38 \mathrm{~cm}^{-1}$ presented the $\mathrm{C}-\mathrm{O}$ stretching vibration in the lignin structure [135] [136] and the shifting from 1058.38 to $1060.02 \mathrm{~cm}^{-1}$ clearly showed the interaction of copper(II) with oxygen lone pair [136]. It can be noticed that, the characteristic peaks intensities were increased from 1621.11, 1460.88, 1316.25, 1157.61, 1102.87 and 1058.38 $\mathrm{cm}^{-1}$ to $1625.70,1462.09,1317.76,1161.37,1104.25$ and $1060.02 \mathrm{~cm}^{-1}$ respectively. The band at $956.48 \mathrm{~cm}^{-1}$ is correlating to $=\mathrm{C}-\mathrm{H}$ indicating the presence of alkenes [137] and after adsorption it was varied to be $956.25 \mathrm{~cm}^{-1}$. The peak at $886.77 \mathrm{~cm}^{-1}$ is representative for the out-of-plane $\mathrm{C}-\mathrm{H}$ bending motions in terminal methylene groups [138] which was shifted to $890.83 \mathrm{~cm}^{-1}$. The peaks at 780.14 and $667.22 \mathrm{~cm}^{-1}$ refer to $\mathrm{C}-\mathrm{H}$ out-of-plane bending (alkenes) and $\mathrm{O}-\mathrm{H}$ out-of-plane bending (alcohols and phenols) respectively [139] [140]. The peak shown at $515.57 \mathrm{~cm}^{-1}$ is from $\mathrm{O}-\mathrm{C}-\mathrm{O}$ in plane bending [141]. These peaks around $780.14 \mathrm{~cm}^{-1}$ shifted to $781.05 \mathrm{~cm}^{-1}, 667.22 \mathrm{~cm}^{-1}$ shifted to $670.44 \mathrm{~cm}^{-1}$ and $515.57 \mathrm{~cm}^{-1}$ changed to $516.00 \mathrm{~cm}^{-1}$.

After the sesame husk was loaded with copper, it was observed that there are differences in the intensities or the locations of the absorbance peaks. This shift in wave number corresponds to a change in bonding energy of the functional groups such as hydroxyl, amine group, carbonyl and carboxyl groups, alkenes groups or oxygen lone pair. This FT-IR result indicates that these functional groups in the sesame husk participated in the adsorption process and binding of copper ions [84] [115] [142] [143] [144].

\subsubsection{Scanning Electron Microscopy}

Scanning electron microscopy (SEM) was used to analyze the surface morphology and fundamental physical properties of the adsorbent. The scanning electron micrographs before and after adsorption were shown in Figure 9. Before adsorption, The morphology of sesame husk ( $\mathrm{SH}$ ) adsorbent exhibited a rough and irregular surface with a distinguished dark spots of pores and cavities, implying that there was a possibility for $\mathrm{Cu}(\mathrm{II})$ metal ions to be trapped and adsorbed onto the surface. After adsorption, SEM image clearly showed that the pores were completely filled and the $\mathrm{SH}$ surface was more regular and relatively smoother with several agglomeration, indicating that copper metal ions have been attached to the surface. 

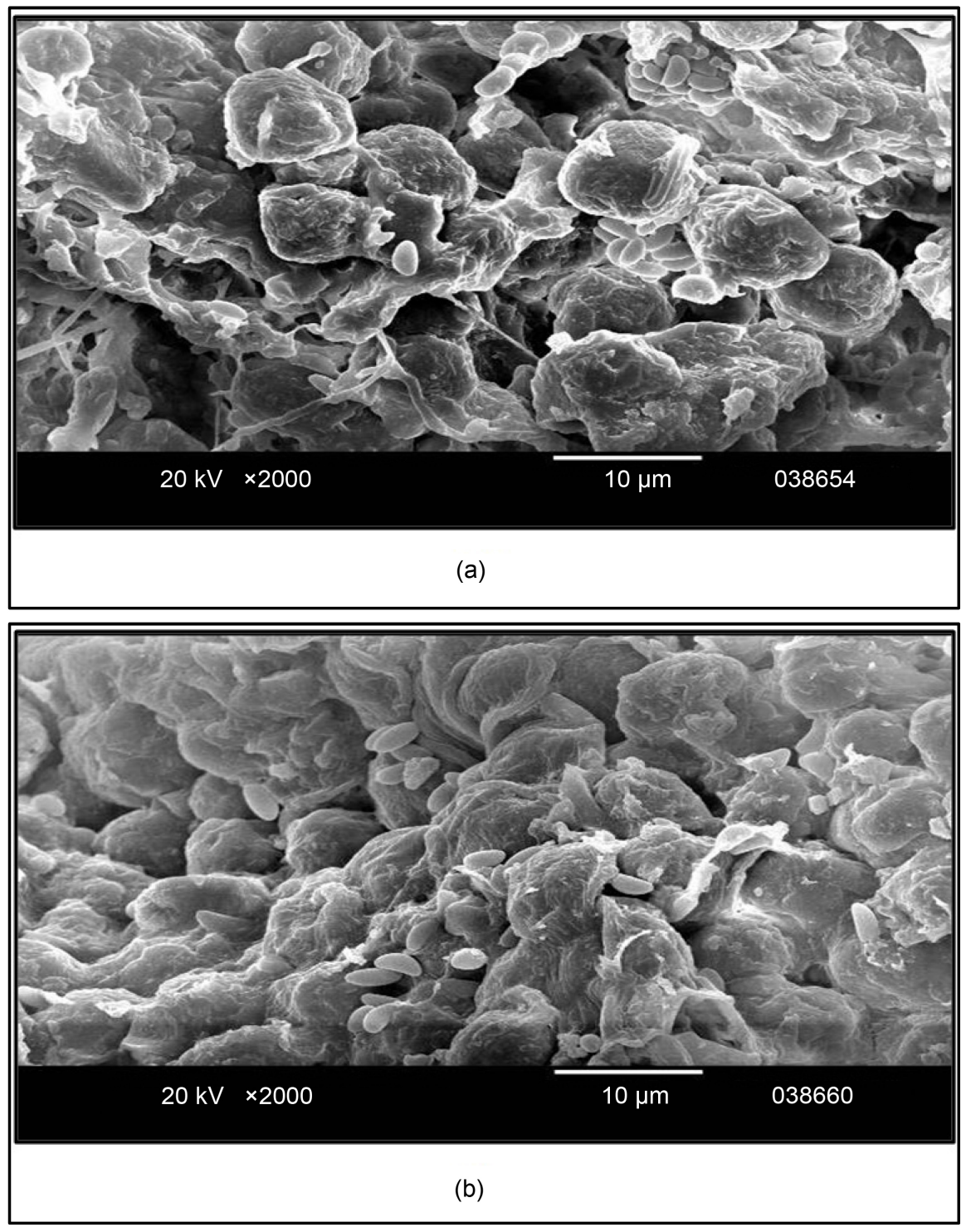

Figure 9. SEM images of sesame husk (a) before adsorption and (b) after adsorption of $\mathrm{Cu}(\mathrm{II})$ ions.

From the characterization of the adsorbent, there is a high affinity between $\mathrm{SH}$ and $\mathrm{Cu}(\mathrm{II})$ ions due to the rough surface and functional groups of sesame husk which adsorb copper metal cations from solution.

\subsection{Adsorption Isotherm Study}

The adsorption isotherm is a primary tool for understanding the surface nature of the adsorbent. However, selecting the right suitable adsorption equation for different concentration ranges presents a clear picture of the surface.

The adsorption isotherm is significant to describe the following: 1) distribution of adsorbate molecules between the liquid and solid phase at equilibrium, 2) the manner of interaction between adsorbate and adsorbent and 3) the adsorption type and its features. For determining the adsorption system, the data were fitted for applying different models [145] such as Langmuir, Freundlich and Du- 
binin-Radushkevich (D-R) isotherms.

\subsubsection{Langmuir Isotherm}

The Langmuir adsorption isotherm assumes that adsorption takes place at totally homogenous adsorption surface [13] [64] [146] [147]. Further assumption is that the maximum adsorption corresponds to a saturated monolayer of adsorbate molecules on adsorbent surface and there is no significant interaction among adsorbed species. Thus, the adsorption energy is constant and there is no transmigration of adsorbate in the plane of the adsorbent surface [148] [149] [150] [151].

The equilibrium data for metal cations have been correlated with the Langmuir isotherm over the concentration range of copper metal ions from 30 to 100 $\mathrm{mg} / \mathrm{L}$ at $298 \mathrm{~K}$. The Langmuir isotherm represented by the following equation [152]:

$$
\frac{C_{e}}{q_{e}}=\frac{1}{q_{\max } \cdot b}+\frac{1}{q_{\max }} C_{e}
$$

$q_{e}(\mathrm{mg} / \mathrm{g})$ is the equilibrium adsorption capacity of ions on the adsorbent, $C_{e}$ $(\mathrm{mg} / \mathrm{L})$ is the equilibrium ion concentration in solution, $q_{\max }(\mathrm{mg} / \mathrm{g})$ is the maximum capacity of the adsorbent, which represents monolayer coverage of adsorbent with adsorbate, $b(\mathrm{~L} / \mathrm{mg})$ is the Langmuir adsorption constant. $q_{\max }$ and $b$ are Langmuir constants related to adsorption efficiency and energy of adsorption respectively [149]. As shown in Figure 10, the linear plot of $C_{e} / q_{e}$ versus $C_{e}$ suggests the applicability of the Langmuir isotherm with a slope of $\frac{1}{q_{\max }}$ and intercept of $\frac{1}{q_{\max } \cdot b}$. The Langmuir model effectively described the adsorption data with $\mathrm{R}^{2}$ value larger than 0.97 .

The adsorption isotherms of $\mathrm{Cu}(\mathrm{II})$ exhibit Langmuir behavior, which indicates a monolayer adsorption and the applicability of adsorption process can be

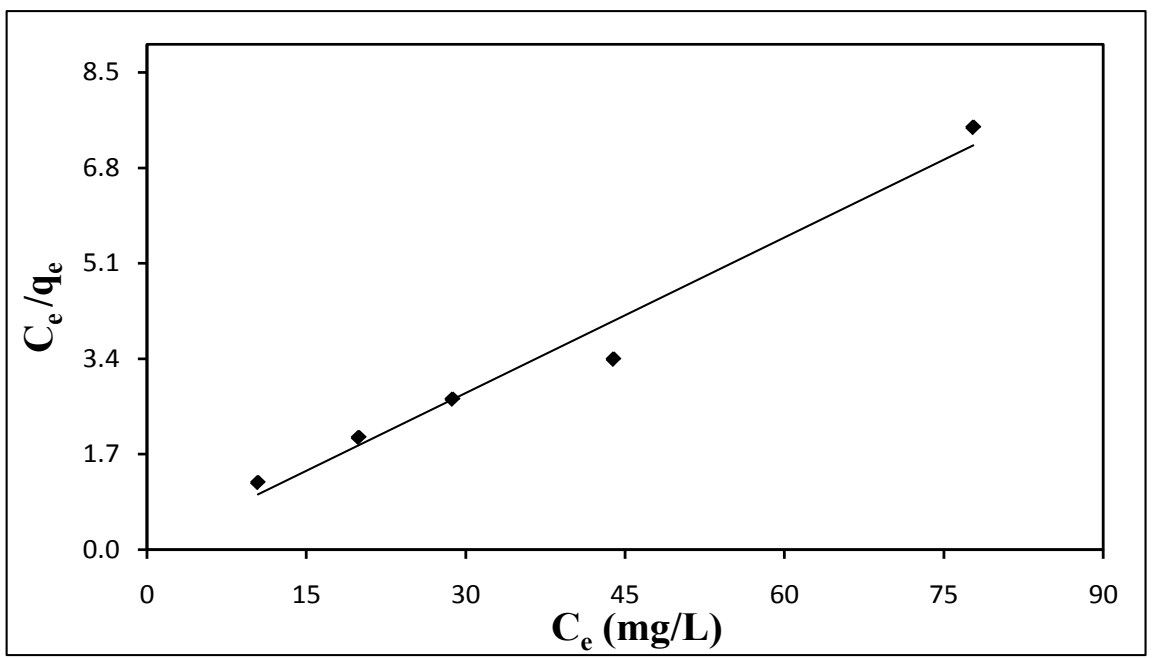

Figure 10. The linearized Langmuir adsorption isotherm for $\mathrm{Cu}(\mathrm{II})$ ions adsorption by sesame husk ( T: $298 \mathrm{~K}, \mathrm{pH}:$ 6, $300 \mathrm{rpm}$ and $1.0 \mathrm{~g}$ of adsorbent for $30 \mathrm{~min}$ ). 
identified by dimensionless constant separation factor $\left(R_{L}\right)$ [153] which is shown below:

$$
R_{L}=\frac{1}{1+b C_{i}}
$$

where $C_{i}$ is the initial concentration of $\mathrm{Cu}(\mathrm{II})$. The $R_{L}$ value indicates whether the adsorption is: Unfavorable: $R_{L}>1$; Linear: $R_{L}=1$; Favorable: $0<R_{L}<1$; Irreversible: $R_{L}=0$. As presented in Table 3, $R_{L}$ values were 0.008, 0.005, 0.004, 0.003 and 0.002 for initial concentration of 30, 40, 50, 70 and $100 \mathrm{mg} / \mathrm{L}$ respectively. Since the $R_{L}$ values are found to be in the range between 0 and 1, this indicates that the adsorption of $\mathrm{Cu}(\mathrm{II})$ metal cations onto the adsorbent (sesame husk) is favorable [13] [88] [154] [155].

\subsubsection{Freundlich Isotherm}

The Freundlich isotherm gives the relationship between equilibrium liquid and solid phase capacity consisting of heterogeneous surface of the adsorbent or surface supporting sites of diverse affinities [151] [156] [157] and this isotherm is applicable to multilayer sorption [64]. It states that the ratio of the amount of solute adsorbed onto a given mass of adsorbent to the concentration of the solute in the solution is not constant at different concentrations [158].

The logarithmic form of Freundlich [159] is represented by the following Equation:

$$
\log \left(q_{e}\right)=\log \left(K_{f}\right)+\frac{1}{n} \log \left(C_{e}\right)
$$

Equilibrium capacity $q_{e}$ and $C_{e}$ are defined as above while $K_{f}$ is the Freundlich adsorption constant representing the adsorption capacity, $n$ is the empirical parameter relating the adsorption intensity of the solid adsorbent which varies with the heterogeneity of material. The magnitude of $n$ gives a measure of the favorability of adsorption. If the value of $n$ between 1 and $10(1 / n$ is lower than 1 ), this represents that the surface of the adsorbent was heterogeneous and adsorption occurred easily [64] [151] [157] [160] [161].

Table 3. Parameters of Langmuir, Freundlich and Dubinin-Radushkevich (D-R) iso-

\begin{tabular}{|c|c|c|c|c|c|c|c|c|c|}
\hline \multicolumn{10}{|c|}{ Adsorption isotherm model } \\
\hline \multicolumn{2}{|c|}{ Langmuir } & \multicolumn{3}{|c|}{ Freundlich } & \multicolumn{5}{|c|}{ Dubinin-Radushkevich (D-R) } \\
\hline $\begin{array}{cc}q_{\max } & b \\
(\mathrm{mg} / \mathrm{g}) & (\mathrm{L} / \mathrm{mg})\end{array}$ & $\begin{array}{c}R_{L} \\
\text { (at different } \\
\text { concentrations) }\end{array}$ & $R^{2}$ & $n$ & $\begin{array}{c}K_{f} \\
(\mathrm{~L} / \mathrm{g})\end{array}$ & $R^{2}$ & $\begin{array}{c}X_{m} \\
(\mathrm{mg} / \mathrm{g})\end{array}$ & $\begin{array}{c}\beta \\
\left(\mathrm{mol}^{2} / \mathrm{J}^{2}\right)\end{array}$ & $\begin{array}{c}E \\
(\mathrm{~kJ} / \mathrm{mol})\end{array}$ & $R^{2}$ \\
\hline \multirow{5}{*}{$10.83 \quad 4.569$} & 0.008 (at $30 \mathrm{mg} / \mathrm{L}$ ) & & & & & & & & \\
\hline & $0.005($ at $40 \mathrm{mg} / \mathrm{L})$ & & & & & & & & \\
\hline & & 0.9740 & 8.210 & 6.933 & 0.4197 & 11.37 & $5.0 \times 10^{-6}$ & 0.316 & 0.6046 \\
\hline & $0.003($ at $70 \mathrm{mg} / \mathrm{L})$ & & & & & & & & \\
\hline & 0.002 (at $100 \mathrm{mg} / \mathrm{L}$ ) & & & & & & & & \\
\hline
\end{tabular}
therms for the adsorption of $\mathrm{Cu}(\mathrm{II})$ ions onto sesame husk. 
When $\log q_{e}$ is plotted against $\log C_{e}$ a straight line with a slope $1 / n$ and intercept $\log K_{f}$ as obtained in Figure 11. In this study, the Freundlich plots yielded values for the coefficients $K_{f}$ and $n$ were 6.933 and 8.210 respectively as appears in Table 3. This $n$ value indicates that the adsorption intensity is favorable [162] [163].

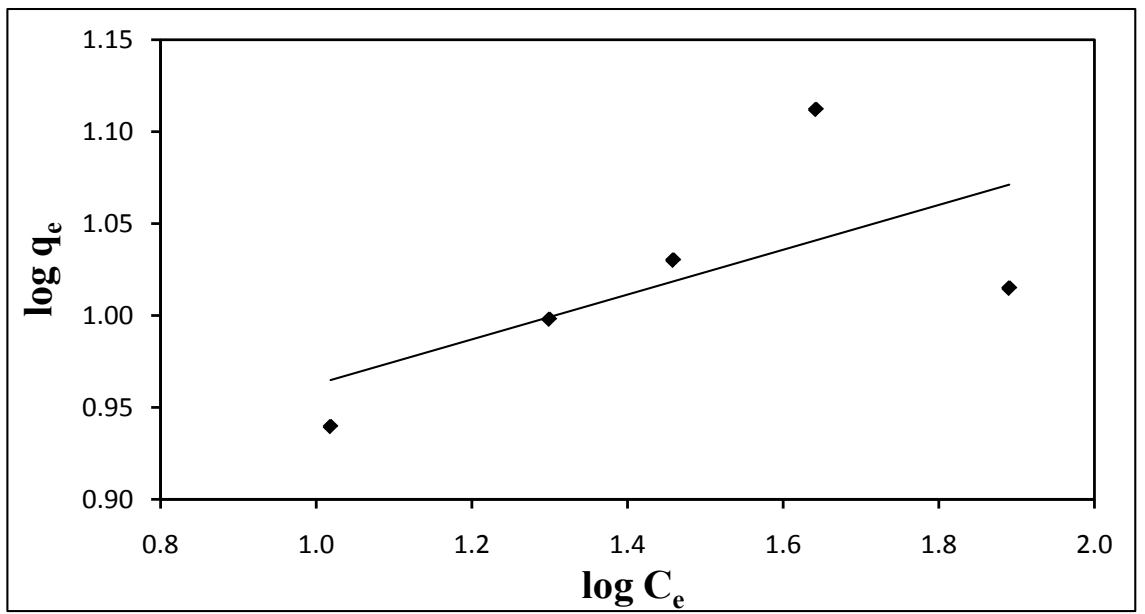

Figure 11. Freundlich adsorption isotherm for $\mathrm{Cu}(\mathrm{II})$ ions adsorption by sesame husk ( $T$ : $298 \mathrm{~K}, \mathrm{pH}: 6,300 \mathrm{rpm}$ and $1.0 \mathrm{~g}$ of adsorbent for $30 \mathrm{~min}$ ).

\subsubsection{Dubinin-Radushkevich (D-R) Isotherm}

The Dubinin-Radushkevich (D-R) isotherm [164] explains multilayer formation in microporous solids. The Dubinin-Kaganer-Radushkevich (DKR) equation more general than the Langmuir isotherm since it does not assume a homogeneous surface or constant adsorption potential whereas it has been widely used to explain energetic heterogeneity of solid surfaces at low coverage. It was applied in order to distinguish between physical and chemical adsorptions [88] [147] [165]. The D-R equation has the following form:

$$
\ln q_{e}=\ln \left(X_{m}\right)-\beta \varepsilon^{2}
$$

$X_{m}(\mathrm{mg} / \mathrm{g})$ is the theoretical monolayer saturation capacity, $\left.\beta\left(\mathrm{mol}^{2} / \mathrm{kJ}\right)^{2}\right)$ is the activity coefficient related to the mean free energy of adsorption per mole of the adsorbate when it is transferred from infinity in the solution to the surface of the solid and $\mathcal{E}(\mathrm{J} / \mathrm{mol})$ is Polanyi potential which is equal to:

$$
\varepsilon=R T \ln \left(1+\frac{1}{C_{e}}\right)
$$

where $R$ is gas constant $(R=8.314 \mathrm{~J} /(\mathrm{mol} \cdot \mathrm{K}))$ and $T$ is temperature $(\mathrm{K})$.

The mean free energy $E(\mathrm{~kJ} / \mathrm{mol})$ is calculated using the relationship [166] [167] [168]:

$$
E=\sqrt{\frac{1}{2 \beta}}
$$

The plot of $\ln q_{e}$ against $\varepsilon^{2}$ for metal ions adsorption on sesame husk is shown in Figure 12. The slope yields $\beta\left(\mathrm{mol}^{2} / \mathrm{kJ}^{2}\right)$ and the intercept yields the adsorption 
capacity $X_{m}(\mathrm{mg} / \mathrm{g})$. From the results in Table 3, the difference of $q_{\max }$ derived from Langmuir and $X_{m}$ derived from D-R model may be attributed to the different definition of maximum capacity in the two models. In Langmuir model $q_{\max }$ represents the maximum adsorption of metal ions at monolayer coverage, but in D-R model $X_{m}$ represents the maximum adsorption of metal ions at the total specific micropores volume of the adsorbent [88] [169].

The magnitude of $E$ is used for estimating the type of adsorption mechanism. If the magnitude of $E$ is between 8 and $16 \mathrm{~kJ} / \mathrm{mol}$, it is indicated that the adsorption process is chemical adsorption, while for value of $E<8 \mathrm{~kJ} / \mathrm{mol}$; the adsorption process is physical in nature. The $E$ value for $\mathrm{Cu}(\mathrm{II})$ on the sesame husk is $0.316 \mathrm{~kJ} / \mathrm{mol}$. The value of $E$ is below $8 \mathrm{~kJ} / \mathrm{mol}$ which indicates that physical adsorption is involved in the adsorption process [88] [170] [171] [172] [173].

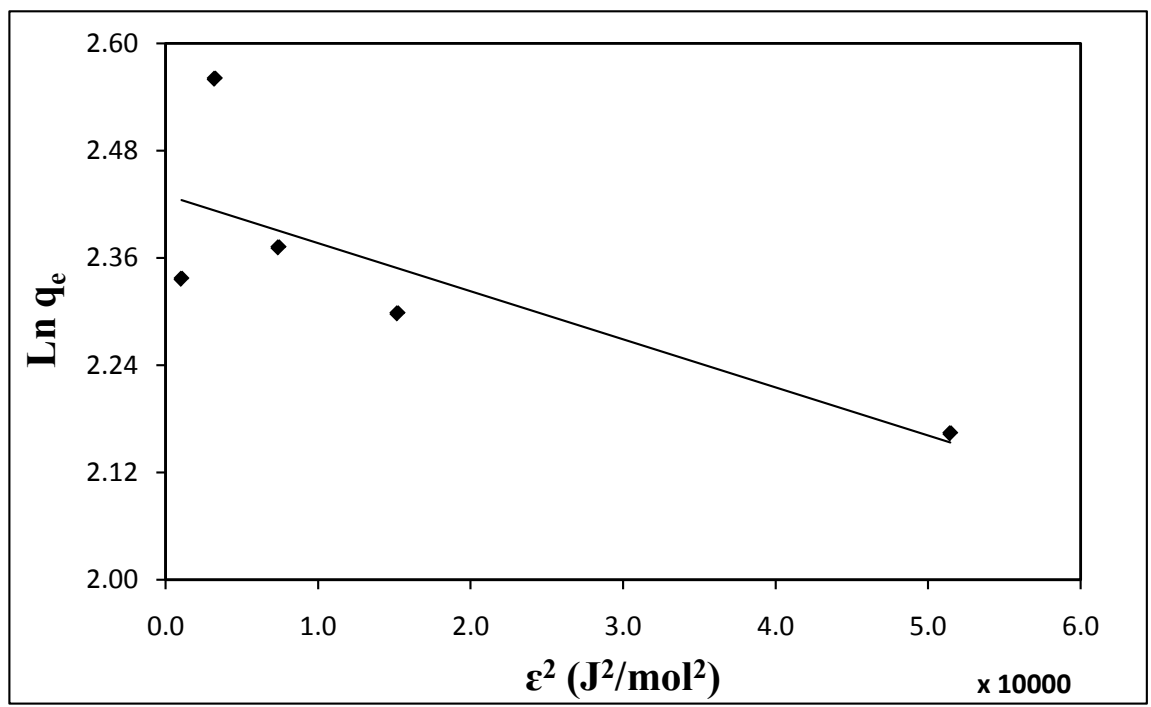

Figure 12. D-R isotherm adsorption plot for $\mathrm{Cu}(\mathrm{II})$ ions onto sesame husk ( T: $298 \mathrm{~K}, \mathrm{pH}$ : $6,300 \mathrm{rpm}$ and $1.0 \mathrm{~g}$ of adsorbent for $30 \mathrm{~min}$ ).

As seen in Table 3 , the value of maximum adsorption capacity $\left(X_{m}\right)$ obtained from D-R model is more than the value of adsorption capacity $\left(q_{\max }\right)$ obtained from the Langmuir isotherm. On the other side, the correlation coefficient value of the linear plot of the Langmuir isotherm $\left(R^{2}=0.9740\right)$ was more satisfactory than those obtained by Freundlich and D-R models $\left(R^{2}=0.4197\right.$ and 0.6046 respectively) which means that Langmuir isotherm model fits quite well with the experimental data and is very suitable for describing the adsorption equilibrium of $\mathrm{Cu}(\mathrm{II})$ on $\mathrm{SH}$. The maximum adsorption capacity $\left(q_{\max }\right)$ of copper ions on $\mathrm{SH}$ was $10.83 \mathrm{mg} / \mathrm{g}$ at $298 \mathrm{~K}$. The complying of results with the Langmuir isotherm may be due to the homogeneous distribution of active sites on SH surface, since the Langmuir equation supposes that the surface is homogeneous.

This is in line with results reported by Cozmuta et al. [174] who studied the adsorption of lead metal ions on Na-clinoptilolite and by Li et al. [175] who studied the adsorption of $\mathrm{Cu}(\mathrm{II})$ ions on amino-functionalized magnetic nanoparticles. 


\subsubsection{Comparison of Maximum Adsorption Capacity of Different Adsorbents for $\mathrm{Cu}(\mathrm{II})$ Ions}

Various adsorbents were investigated for $\mathrm{Cu}(\mathrm{II})$ ions removal. The adsorption capacities of such sorbents are given in Table 4. It is obvious that, the adsorption capacity of sesame husk towards $\mathrm{Cu}(\mathrm{II})$ is comparable or even better than 39 of

Table 4. Comparison of maximum adsorption capacity $\left(q_{\max }\right)$ of different reported adsorbents for $\mathrm{Cu}(\mathrm{II})$ ions.

\begin{tabular}{|c|c|c|c|}
\hline Adsorbent & $q_{\max }$ & \multicolumn{2}{|c|}{ References } \\
\hline Sugarbeet pulp & $0.15 \mathrm{mg} / \mathrm{g}$ & Pehlivan et al. & [176] \\
\hline Grape stalk wastes & $0.78 \mathrm{mg} / \mathrm{g}$ & Villaescusa et al. & [177] \\
\hline Raw pomegranate peel & $1.32 \mathrm{mg} / \mathrm{g}$ & El-Ashtoukhy et al. & [178] \\
\hline Palm shell activated carbon & $1.58 \mathrm{mg} / \mathrm{g}$ & Onundi et al. & [179] \\
\hline Low-rank Turkish coals & $1.62 \mathrm{mg} / \mathrm{g}$ & Karabulut et al. & [180] \\
\hline Sawdust & $1.79 \mathrm{mg} / \mathrm{g}$ & Yu et al. & [181] \\
\hline Bagasse fly ash & $2.26 \mathrm{mg} / \mathrm{g}$ & Gupta and Ali & [182] \\
\hline Modified saw dusts using phosphoric acid (PMSD4) & $2.66 \mathrm{mg} / \mathrm{g}$ & Kalavathy and Miranda & [183] \\
\hline Cocoa shell & $2.86 \mathrm{mg} / \mathrm{g}$ & Meunier et al. & [184] \\
\hline Bagasse & $2.89 \mathrm{mg} / \mathrm{g}$ & Habib et al. & [185] \\
\hline Shells of rice & $2.95 \mathrm{mg} / \mathrm{g}$ & Aydin et al. & [186] \\
\hline Poplar sawdust & $3.24 \mathrm{mg} / \mathrm{g}$ & Šćiban and Klašnja & [187] \\
\hline Almond shell & $3.62 \mathrm{mg} / \mathrm{g}$ & Altun and Pehlivan & [188] \\
\hline Orange peel & $3.65 \mathrm{mg} / \mathrm{g}$ & Annadurai et al. & {$[80]$} \\
\hline Sugarcane bagasse (SB) & $3.65 \mathrm{mg} / \mathrm{g}$ & Putra et al. & [189] \\
\hline Coconut tree sawdust (CTS) & $3.89 \mathrm{mg} / \mathrm{g}$ & Putra et al. & [189] \\
\hline Papaya seed & $3.90 \mathrm{mg} / \mathrm{g}$ & Ahamed and Begum & [190] \\
\hline Elaeis guineensis kernel activated carbon & $3.93 \mathrm{mg} / \mathrm{g}$ & Tumin et al. & {$[90]$} \\
\hline Unmodified jute fibre & $4.23 \mathrm{mg} / \mathrm{g}$ & Shukla and Pai & [191] \\
\hline Groundnut shells & $4.46 \mathrm{mg} / \mathrm{g}$ & Shukla and Pai & [192] \\
\hline Banana peel & $4.75 \mathrm{mg} / \mathrm{g}$ & Annadurai et al. & {$[80]$} \\
\hline $\mathrm{H}_{3} \mathrm{PO}_{4}$-activated rubber wood sawdust & $5.73 \mathrm{mg} / \mathrm{g}$ & Kalavathy et al. & [193] \\
\hline Cotton fibre & $6.12 \mathrm{mg} / \mathrm{g}$ & Paulino et.al. & [194] \\
\hline Hazelnut shell & $6.65 \mathrm{mg} / \mathrm{g}$ & Altun and Pehlivan & [188] \\
\hline Walnut shell & $6.74 \mathrm{mg} / \mathrm{g}$ & Altun and Pehlivan & [188] \\
\hline $\mathrm{NaOH}$ modified sawdust (poplar tree) & $6.92 \mathrm{mg} / \mathrm{g}$ & Šćiban et al. & {$[57]$} \\
\hline Phosphate rock & $7.24 \mathrm{mg} / \mathrm{g}$ & Cao et al. & [195] \\
\hline Corn cobs & $7.62 \mathrm{mg} / \mathrm{g}$ & Reddad et.al. & [196] \\
\hline Oxidized jute & $7.73 \mathrm{mg} / \mathrm{g}$ & Shukla and Pai & [191] \\
\hline Wheat shell & $8.34 \mathrm{mg} / \mathrm{g}$ & Basci et al. & [197] \\
\hline Peanut hulls & $8.37 \mathrm{mg} / \mathrm{g}$ & Brown et al. & [198] \\
\hline Corn starch & $8.57 \mathrm{mg} / \mathrm{g}$ & Reddad et.al. & [196] \\
\hline Tea-industry waste & $8.64 \mathrm{mg} / \mathrm{g}$ & Çay et al. & [199] \\
\hline Rubber tree leaf & $8.92 \mathrm{mg} / \mathrm{g}$ & Ngah and Hanafiah & [200] \\
\hline Coir fibre & $9.43 \mathrm{mg} / \mathrm{g}$ & Shukla and Shukla & {$[201]$} \\
\hline Pine bark & $9.47 \mathrm{mg} / \mathrm{g}$ & Al-Asheh et al. & {$[202]$} \\
\hline Maple wood sawdust & $9.51 \mathrm{mg} / \mathrm{g}$ & Rahman and Islam, & [203] \\
\hline Shells of lentil & $9.59 \mathrm{mg} / \mathrm{g}$ & Aydin et.al. & [186] \\
\hline Apple wastes & $10.80 \mathrm{mg} / \mathrm{g}$ & Lee and Yang & {$[204]$} \\
\hline Volcanic rock & $10.87 \mathrm{mg} / \mathrm{g}$ & Sekomo et al. & {$[205]$} \\
\hline Oil palm leaf powders & $11.22 \mathrm{mg} / \mathrm{g}$ & Sulaiman et al. & [206] \\
\hline Cotton boll & $11.40 \mathrm{mg} / \mathrm{g}$ & Ozsoy and Kumbur & {$[207]$} \\
\hline Tree fern & $11.70 \mathrm{mg} / \mathrm{g}$ & Ho & [208] \\
\hline Sesame husk (Langmuir model) & $10.83 \mathrm{mg} / \mathrm{g}$ & Present study & \\
\hline Sesame husk (D-R model) & $11.37 \mathrm{mg} / \mathrm{g}$ & Present study & \\
\hline
\end{tabular}


43 other reported adsorbents, referring the promising future for sesame husk utilization in copper ions removal from aqueous solutions.

\subsection{Adsorption Kinetics}

Several adsorption kinetic models such as pseudo first-order, pseudo secondorder and intra-particle diffusion models had been used to understand the characteristics and mechanism of adsorption [209] and the rate-limiting step during adsorption process [88].

\subsubsection{Pseudo First-Order Model}

The adsorption rate constant suggested by Lagergren [210] and Ho [211] by applying first-order reaction kinetic is given by Equation (11):

$$
\frac{\mathrm{d} q_{t}}{\mathrm{~d} t}=k_{1}\left(q_{e}-q_{t}\right)
$$

where $k_{1}$ is the adsorption rate constant for the first order adsorption, $q_{t}(\mathrm{mg} / \mathrm{g})$ is the amount of $\mathrm{Cu}(\mathrm{II})$ metal adsorbed at time $t$ and $q_{e}(\mathrm{mg} / \mathrm{g})$ is the amount of heavy metal adsorbed at saturation.

The integration of the Equation (11) gives the following expression:

$$
\ln \left(q_{e}-q_{t}\right)=-k_{1} t+C_{1}
$$

where $C_{I}$ is the integration constant for first-order reaction kinetic.

If it is supposed that $q=0$ at $t=0$, then the pseudo first-order kinetic model is expressed by:

$$
\ln \left(q_{e}-q_{t}\right)=\ln q_{e}-k_{1} t
$$

where $q_{e}$ and $q_{t}(\mathrm{mg} / \mathrm{g})$ are the amounts of $\mathrm{Cu}(\mathrm{II})$ ions adsorbed onto sesame husk at equilibrium and at time $t$, respectively and $k_{1}\left(\mathrm{~min}^{-1}\right)$ is the rate constant of pseudo first-order kinetic model.

The straight line plots of $\ln \left(q_{e}-q_{t}\right)$ against $t$ were used to determine the $k_{1}$ and theoretical $q_{e}$ As seen in Figure 13 although the plot was linear, the calculated

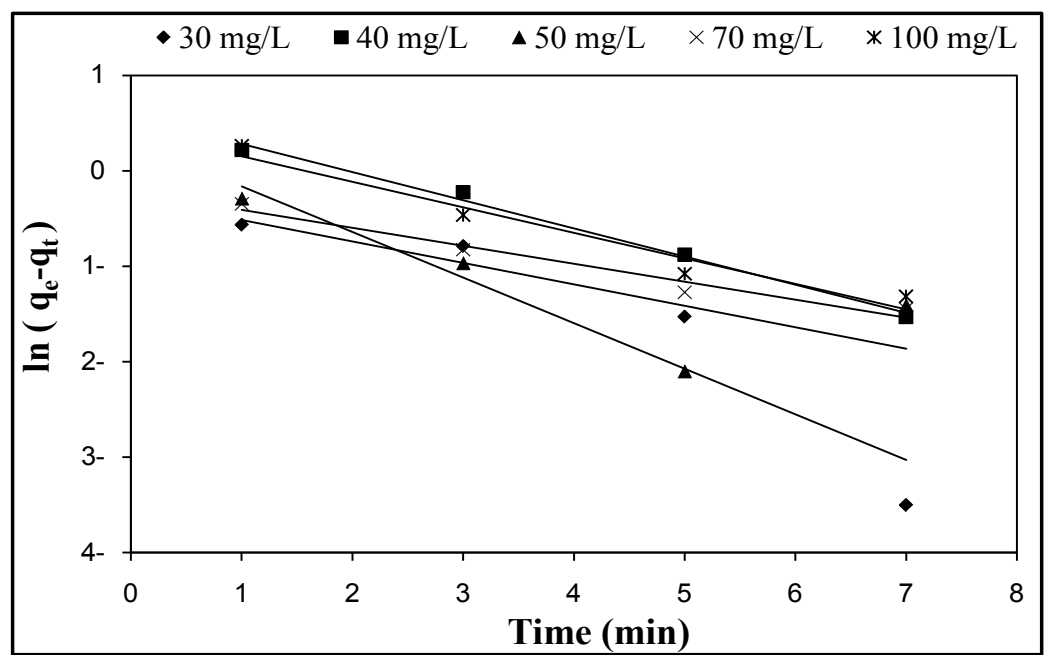

Figure 13. Pseudo first-order plot for the adsorption of $\mathrm{Cu}(\mathrm{II})$ ions onto sesame husk at different initial concentrations (T:298 K, $300 \mathrm{rpm}, \mathrm{pH}: 6$ and $1.0 \mathrm{~g}$ of adsorbent). 
value $\left(q_{e, \text { calc. }}\right)$ and the experimental value $\left(q_{e, \text { exp. }}\right)$ were not in agreement with each other referring a poor pseudo first-order kinetic model fit. Moreover, this kinetic model does not fit well to the whole range of contact time. It could only be applied over the initial stage of the adsorption process (1 - 7 minutes) [88] [212] [213].

\subsubsection{Pseudo Second-Order}

The pseudo second-order model [214] [215] based on equilibrium adsorption is evaluated using the relationship:

$$
\frac{t}{q_{t}}=\frac{1}{k_{2} q_{e}^{2}}+\frac{1}{q_{e}} t
$$

where $k_{2}$ is the rate constant of pseudo second-order kinetic model $(\mathrm{g} /(\mathrm{mg}$. $\min$ )). The straight line plots of $t / q_{t}$ against $t$ (Figure 14) were used to determine the $k_{2}$ and $q_{e, \text { calc. }}$. This model was more likely to predict the behavior over whole range of contact time. According to results in Table 5, the $R^{2}$ value for the pseudo second-order kinetic model was very close or even equal to unity. Moreover, the calculated equilibrium adsorption capacity values $q_{e, \text { calc. }}$ were very close to the experimental $q_{e \text { exp. }}$ values indicating that the adsorption process of copper ions onto SH obeys pseudo second-order model kinetics at all initial $\mathrm{Cu}$ (II) concentrations.

In general, the adsorption process on a porous adsorbent will have four main stages. These stages involve: 1) the movement of the adsorbate from the bulk solution to the exterior film surrounding the adsorbent particle (bulk solution transport), 2) the transport of adsorbate across the external liquid film to the external surface sites on the adsorbent particle (film diffusion transport), 3) Migration of adsorbate within the pores of the adsorbent by intra-particle diffusion (pore diffusion) and finally 4) adsorption of adsorbate at internal surface sites [216] [217].

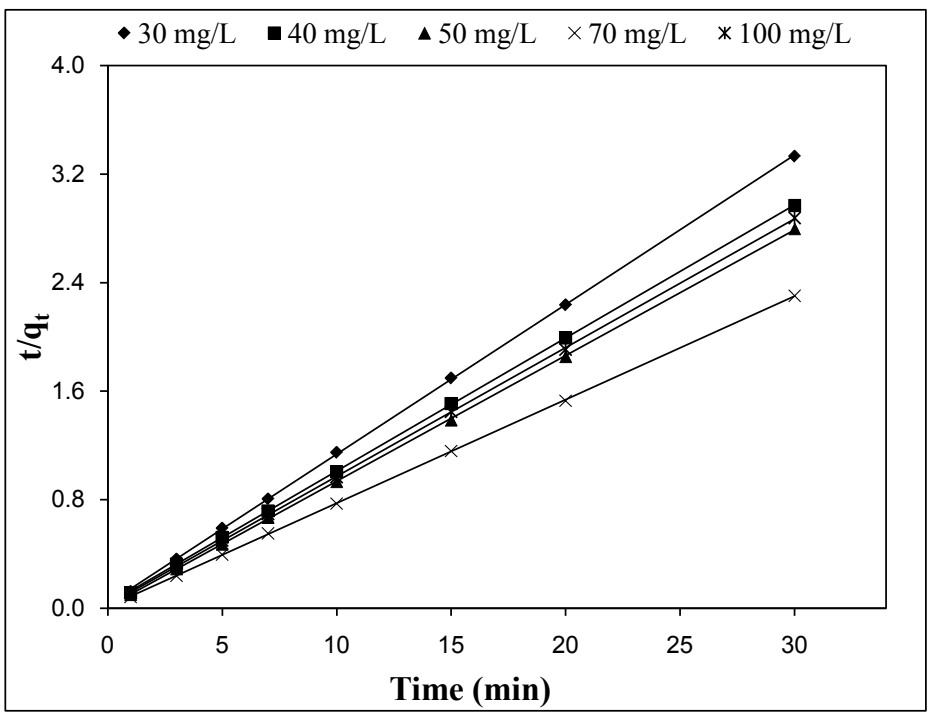

Figure 14. Pseudo second-order plot for the adsorption of $\mathrm{Cu}$ (II) ions onto sesame husk at different initial concentrations ( T: $298 \mathrm{~K}, 300 \mathrm{rpm}, \mathrm{pH}: 6$ and $1.0 \mathrm{~g}$ of adsorbent). 
Table 5. Comparison of kinetic parameters for the adsorption of $\mathrm{Cu}(\mathrm{II})$ ions onto sesame husk at different concentration ( $T: 298 \mathrm{~K}$, speed: $300 \mathrm{rpm}$, pH: 6 and $1.0 \mathrm{~g}$ of adsorbent).

\begin{tabular}{|c|c|c|c|c|c|c|}
\hline \multirow{3}{*}{ Kinetic model } & \multirow[b]{2}{*}{ parameters } & \multicolumn{5}{|c|}{ Concentration $(\mathrm{mg} / \mathrm{L})$} \\
\hline & & $\begin{array}{c}30 \\
\mathrm{mg} / \mathrm{L}\end{array}$ & $\begin{array}{c}40 \\
\mathrm{mg} / \mathrm{L}\end{array}$ & $\begin{array}{c}50 \\
\mathrm{mg} / \mathrm{L}\end{array}$ & $\begin{array}{c}70 \\
\mathrm{mg} / \mathrm{L}\end{array}$ & $\begin{array}{c}100 \\
\mathrm{mg} / \mathrm{L}\end{array}$ \\
\hline & $q_{e, \text { exp. }}(\mathrm{mg} / \mathrm{g})$ & 8.704 & 9.954 & 10.72 & 12.94 & 10.35 \\
\hline \multirow{5}{*}{ Pseudo first-order } & $q_{e, \text { calc. }}(\mathrm{mg} / \mathrm{g})$ & 1.371 & 1.782 & 0.746 & 0.800 & 1.521 \\
\hline & $k_{1}\left(\min ^{-1}\right)$ & 0.478 & 0.295 & 0.225 & 0.188 & 0.267 \\
\hline & $R^{2}$ & 0.8521 & 0.9924 & 0.5798 & 0.9649 & 0.9579 \\
\hline & $\Delta q_{e}(\%)$ & 97.62 & 94.92 & 107.5 & 108.4 & 98.59 \\
\hline & $q_{e, \text { calc. }}(\mathrm{mg} / \mathrm{g})$ & 9.066 & 10.19 & 10.79 & 13.11 & 10.53 \\
\hline \multirow{4}{*}{$\begin{array}{c}\text { Pseudo } \\
\text { second-order }\end{array}$} & $k_{2}(\mathrm{~g} /(\mathrm{mg} \cdot \mathrm{min}))$ & 0.372 & 0.336 & 0.966 & 0.539 & 0.424 \\
\hline & $R^{2}$ & 0.9999 & 1.0000 & 0.9999 & 1.0000 & 0.9999 \\
\hline & $\Delta q_{e}(\%)$ & 2.961 & 2.234 & 0.534 & 1.130 & 1.495 \\
\hline & $k_{p}\left(\mathrm{mg} /\left(\mathrm{g} \cdot \min ^{1 / 2}\right)\right)$ & 0.205 & 0.298 & 0.160 & 0.180 & 0.283 \\
\hline \multirow{3}{*}{$\begin{array}{l}\text { Intra-particle } \\
\text { diffusion }\end{array}$} & $C$ & 7.999 & 8.732 & 10.06 & 12.21 & 9.190 \\
\hline & $R^{2}$ & 0.9219 & 0.8068 & 0.6835 & 0.8549 & 0.7514 \\
\hline & $\Delta q_{e}(\%)$ & 3.252 & 3.957 & 2.122 & 1.985 & 3.621 \\
\hline
\end{tabular}

\subsubsection{Intra-Particle Diffusion}

The description of the adsorption process in a well-stirred batch adsorption system which occurs on a porous adsorbent is rebated by applying [218] intra-particle diffusion model. The formation of this model is as follows:

$$
q_{t}=k_{p} t^{1 / 2}+C
$$

where $q_{t}(\mathrm{mg} / \mathrm{g})$ is the amount of $\mathrm{Cu}(\mathrm{II})$ ions adsorbed onto sesame husk at time $t$, and $k_{p}\left(\mathrm{mg} /\left(\mathrm{g} \cdot \mathrm{min}^{1 / 2}\right)\right)$ is the intra-particle diffusion rate constant. The straight line plots of $q_{t}$ against $t^{1 / 2}$ were used to determine the intra-particle diffusion rate ( $k_{p}$, slope), correlation coefficient $R^{2}$ and the intra-particle diffusion constant $\mathrm{mg} / \mathrm{g}(C$, intercept) related to the thickness of the boundary layer: the larger the intercept, the greater the boundary layer effect [219] as shown in Table 5.

Based on Figure 15, the plot showed multi-linearity correlation which reveals that more than one step occurred during the adsorption process. Step "one" is the diffusion through the solution to the external surface of the adsorbent (the initial linear portions) which is also known as external mass transfer or film diffusion [220], whereas step "two" corresponds to the intra-particle diffusion into the porous structure of the adsorbent [74] [221]. The later horizontal portions of the plot were slow and controlled by equilibrium diffusion mechanism [222].

If Weber-Morris plot $\left(q_{t}\right.$ against $\left.t^{1 / 2}\right)$ is linear, so intra-particle diffusion occurs. And if the line passes through the origin, then the intra-particle diffusion is the only rate-limiting step [223]. In the current study, the plots of the intra-particle diffusion model did not pass through the origin indicating that the intra-particle diffusion is not the sole limiting-step but the film diffusion also played an important role in adsorption. This is in coincidence with the fact that the adsorption processes followed pseudo second-order model [224]. 


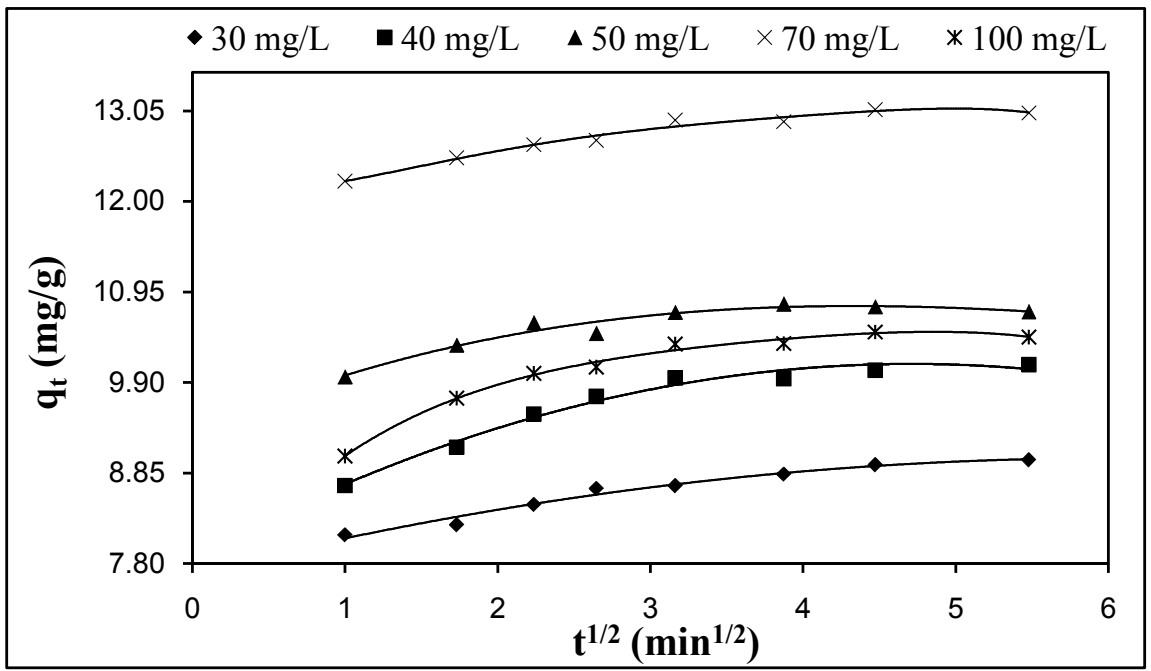

Figure 15. Intra-particle diffusion fit for the adsorption of $\mathrm{Cu}$ (II) ions onto sesame husk at different initial concentrations ( T: $298 \mathrm{~K}, 300 \mathrm{rpm}, \mathrm{pH}$ : 6 and $1.0 \mathrm{~g}$ of adsorbent).

\subsubsection{Test of Kinetic Validity:}

To check quantitatively the validity of the used kinetic models in this study, a normalized standard deviation $\Delta q_{e}$ (\%) is calculated by the following equation [225] [226]:

$$
\Delta q_{e}(\%)=\sqrt{\frac{\sum\left[\left(q_{e, \text { exp. }}-q_{e, \text { calc. }}\right) / q_{e, \text { exp. }}\right]^{2}}{n-1}}
$$

where $n$ is the number of data points, $q_{e, \text { exp. }}(\mathrm{mg} / \mathrm{g})$ is the observed experimental value, $q_{e, \text { calc. }}(\mathrm{mg} / \mathrm{g})$ is the calculated $q_{e}$ from the models and the calculated results are listed in Table 5. It was found that the pseudo second-order kinetic model yielded the lowest $\Delta q_{e}(\%)$ values. This agrees with the earlier obtained $R^{2}$ values and confirms that the adsorption of $\mathrm{Cu}(\mathrm{II})$ ions onto sesame husk can be best described by the pseudo second-order kinetic model; the values of correlation coefficients $\left(R^{2}\right)$ obtained for the linear plots from the pseudo second-order model are greater than those obtained for the pseudo first-order and intra-particle diffusion models under all conditions studied. Also, the values of $\Delta q_{e}(\%)$ obtained for the pseudo second-order model were lower than those obtained from the pseudo first-order and intra-particle diffusion model under all conditions studied. Therefore, the adsorption of $\mathrm{Cu}$ (II) ions onto sesame husk adsorbent can be best described by the pseudo second-order kinetic model due to the higher correlation coefficient and a good agreement between the experimental and the calculated $q_{e}$ value.

\subsection{Type of Adsorption}

The type of adsorption can be estimated from four parameters $\Delta H^{\circ}$, activation energy $E_{a}$ the mean free energy $E=\sqrt{1 / 2 \beta}$ and effect of temperature as follows:

The negative value of $\Delta H^{\circ}$ for adsorption of $\mathrm{Cu}$ ions implies that the adsorption phenomenon is exothermic in nature [109]. According to literature [227] [228] [229], if the enthalpy change value $\Delta H^{\circ}$ of adsorbent is higher than 40 
$\mathrm{kJ} / \mathrm{mol}$, the process is chemisorption which includes strong electrostatic chemical bonding between metal ions and adsorbent surface and when enthalpy change value is less than $20 \mathrm{~kJ} / \mathrm{mol}$, it indicates the adsorption is physical in nature. In this study, the $\Delta H^{o}$ value for adsorption was $-68.48 \mathrm{~kJ} / \mathrm{mol}$ for $\mathrm{Cu}$ which reveal that the chemical adsorption (chemisorption) is involved for adsorption of $\mathrm{Cu}$ ions on $\mathrm{SH}$ adsorbent.

The magnitude of activation energy gives an idea about the type of sorption. Low activation energies $E_{a}(5-40 \mathrm{~kJ} / \mathrm{mol})$ are characteristics for physisorption, while higher activation energies $(40-800 \mathrm{~kJ} / \mathrm{mol})$ suggest chemisorption [230] [231]. The obtained $E_{a}$ value $(112.37 \mathrm{~kJ} / \mathrm{mol})$ indicates that the adsorption between $\mathrm{Cu}$ metal ions and adsorbent corresponds to chemisorption.

The magnitude of $E$ is used for estimating the type of adsorption mechanism. If the magnitude of $E$ is between 8 and $16 \mathrm{~kJ} / \mathrm{mol}$, it is indicated that the adsorption process is chemical adsorption, while for value of $E<8 \mathrm{~kJ} / \mathrm{mol}$; the adsorption process is physical in nature (physisorption). The $E$ value for $\mathrm{Cu}(\mathrm{II})$ on the sesame husk was $0.316 \mathrm{~kJ} / \mathrm{mol}$. The value of $E$ is below $8 \mathrm{~kJ} / \mathrm{mol}$ which refer that; physical adsorption is involved in the adsorption process on the adsorbent surface [88] [170] [171] [172] [173].

The trend of adsorption upon increasing the temperature can refer to the type of adsorption mechanism. In physical adsorption (physisorption), the force of attraction existing between adsorbate and adsorbent are Vander Waal's forces (the force of attraction between the adsorbate and adsorbent are weak), therefore this type of adsorption can be easily reversed by heating or by decreasing the pressure which is called desorption. While in chemical adsorption (chemisorption), the adsorbate is chemically bound to the adsorbent and as a result, the forces between the two become 10 - 100 times greater than in physisorption [232] [233]. In the present study, the adsorption decreased upon rising temperature; this reversible behavior indicates that "physical adsorption occurred".

These results suggested that the adsorption of copper(II) ions onto SH involves chemisorption as well as physisorption mechanism. From literature [149] [234] [235], both physical and chemical adsorption may occur on the surface at the same time; a layer of molecules may be physically adsorbed on top of an underlying chemisorbed layer.

\section{Conclusion}

The present study highlighted the ability of sesame husk (SH) to adsorb $\mathrm{Cu}$ (II) from aqueous solutions. Experimental data are in alignment with Langmuir adsorption isotherm and the adsorption process complies well with pseudo second-order kinetic model. The adsorptive capacity of $\mathrm{SH}$ for copper ions is comparable or even better than many other natural adsorbents. The data obtained were used to calculate thermodynamic parameters such as $\Delta G^{o}, \Delta S^{o}$ and $\Delta H^{\circ}$. Intra-particle diffusion is not the sole rate-controlling step. The investigation shows that sesame husk is as a widely available, natural, novel, easy prepared, fast, cheap and efficient adsorbent for the removal of $\mathrm{Cu}$ (II) from 
aqueous solutions $(95.13 \%$ removal of $30 \mathrm{mg} / \mathrm{L} \mathrm{Cu}(\mathrm{II})$ ions solution with small dose of SH $(1.0 \mathrm{~g} / 100 \mathrm{ml})$ within $30 \mathrm{~min}$. only) and thus this adsorbent would exhibit a promising technique for industrial wastewater cleanup.

\section{References}

[1] de Luna, M.D., Flores, E.D., Cenia, M.C. and Lu, M.C. (2015) Removal of Copper Ions from Aqueous Solution by Adlai Shell (Coix lacryma-jobi L.) Adsorbents. Bioresource Technology, 192, 841-844. https://doi.org/10.1016/j.biortech.2015.06.018

[2] Vafakhah, S., Bahrololoom, M.E., Bazarganlari, R. and Saeedikhani, M. (2014) Removal of Copper Ions from Electroplating Effluent Solutions with Native Corn Cob And Corn Stalk and Chemically Modified Corn Stalk. Journal of Environmental Chemical Engineering, 2, 356-361. https://doi.org/10.1016/j.jece.2014.01.005

[3] Lee, H.W., Cho, H.J., Yim, J.H., Kim, J.M., Jeon, J.K., Sohn, J.M., Yoo, K.S., Kim, S.S. and Park, Y.K. (2011) Removal of Cu(II)-Ion over Amine-Functionalized Mesoporous Silica Materials. Journal of Industrial and Engineering Chemistry, 17, 504509. https://doi.org/10.1016/j.jiec.2010.09.022

[4] Nilanjana, D. (2010) Recovery of Precious Metals through Biosorption-A Review. Hydrometallurgy, 103, 180-189. https://doi.org/10.1016/j.hydromet.2010.03.016

[5] Lina, R.V. and Nilanjana, D. (2015) Application of Nano-Biocomposites for Remediation of Heavy Metals from Aqueous Environment: An Overview. International Journal of ChemTech Research, 8, 566-571.

[6] Feng, Y.J., Yang, L.S., Liu, J.F. and Logan, B.E. (2016) Electrochemical Technologies for Wastewater Treatment and Resource Reclamation. Environmental Science: Water Research \& Technology, 2, 800-831.

[7] Marder, L., Sulzbach, G.O., Bernardes, A.M. and Ferreira, J.Z. (2003) Removal of Cadmium and Cyanide from Aqueous Solutions through Electrodialysis. Journal of the Brazilian Chemical Society, 14, 610-615. https://doi.org/10.1590/S0103-50532003000400018

[8] Cañizares, P., de Lucas, A., Pérez, Á. and Camarillo, R. (2005) Effect of Polymer Nature and Hydrodynamic Conditions on a Process of Polymer Enhanced Ultrafiltration. Journal of Membrane Science, 253, 149-163.

https://doi.org/10.1016/j.memsci.2004.12.042

[9] Trivunac, K. and Stevanovic, S. (2006) Removal of Heavy Metal Ions from Water by Complexation-Assisted Ultrafiltration. Chemosphere, 64, 486-491.

https://doi.org/10.1016/j.chemosphere.2005.11.073

[10] Kumano, M., Yabutani, T., Motonaka, J., Mishima, Y. and Mishima, Y. (2006) Recovery and Extraction of Heavy Metal Ions Using Ionic Liquid as Green Solvent. International Journal of Modern Physics B, 20, 4051-4056. https://doi.org/10.1142/S0217979206040842

[11] Verma, V.K., Tewari, S. and Rai, J.P.N. (2008) Ion Exchange during Heavy Metal Bio-Sorption from Aqueous Solution by Dried Biomass of Macrophytes. Bioresource Technology, 99, 1932-1938. https://doi.org/10.1016/j.biortech.2007.03.042

[12] Ajmal, M., Khan, A.H., Ahmad, S. and Ahmad, A. (1998) Role of Sawdust in the Removal of Copper (II) from Industrial Wastes. Water Research, 32, 3085-3091. https://doi.org/10.1016/S0043-1354(98)00067-0

[13] Yao, Z.Y., Qi, J.H. and Wang, L.H. (2010) Equilibrium, Kinetic and Thermodynamic Studies on the Biosorption of $\mathrm{Cu}(\mathrm{II})$ onto Chestnut Shell. Journal of Hazardous Materials, 174, 137-143. https://doi.org/10.1016/j.jhazmat.2009.09.027 
[14] Wang, X.S. and Qin, Y. (2005) Equilibrium Sorption Isotherms for $\mathrm{Cu}^{2+}$ on Rice Bran. Process Biochemistry, 40, 677-680. https://doi.org/10.1016/j.procbio.2004.01.043

[15] Mauchauffée, S. and Meux, E. (2007) Use of Sodium Decanoate for Selective Precipitation of Metals Contained in Industrial Wastewater. Chemosphere, 69, 763-768. https://doi.org/10.1016/j.chemosphere.2007.05.006

[16] Mohsen-Nia, M., Montazeri, P. and Modarress, H. (2007) Removal of $\mathrm{Cu}^{2+}$ and $\mathrm{Ni}^{2+}$ from Wastewater with a Chelating Agent and Reverse Osmosis Processes. Desalination, 217, 276-281. https://doi.org/10.1016/j.desal.2006.01.043

[17] El Samrani, A.G., Lartiges, B.S. and Villiéras, F. (2008) Chemical Coagulation of Combined Sewer Overflow: Heavy Metal Removal and Treatment Optimization. Water Research, 42, 951-960. https://doi.org/10.1016/j.watres.2007.09.009

[18] Sud, D., Mahajan, G. and Kaur, M.P. (2008) Agricultural Waste Material as Potential Adsorbent for Sequestering Heavy Metal Ions from Aqueous Solutions-A Review. Bioresource Technology, 99, 6017-6027. https://doi.org/10.1016/j.biortech.2007.11.064

[19] Ahluwalia, S.S. and Goyal, D. (2005) Removal of Heavy Metals by Waste Tea Leaves from Aqueous Solution. Engineering in Life Sciences, 5, 158-162. https://doi.org/10.1002/elsc.200420066

[20] Meena, A.K., Kadirvelu, K., Mishra, G.K., Rajagopal, C. and Nagar, P.N. (2008) Adsorptive Removal of Heavy Metals from Aqueous Solution by Treated Sawdust (Acacia arabica). Journal of Hazardous Materials, 150, 604-611. https://doi.org/10.1016/j.jhazmat.2007.05.030

[21] Gupta, V.K. and Ali, I. (2006) Adsorbents for Water Treatment: Development of Low-Cost Alternatives to Carbon, Encyclopedia of Surface and Colloid Science. 2nd Edition, Taylor and Francis, New York, 149-184.

[22] Manohar, V.D.M., Noeline, B.F. and Anirudhan, T.S. (2006) Adsorption Performance of Alpillared Bentonite Clay for the Removal of Cobalt (II) from Aqueous Phase. Applied Clay Science, 31, 194-206. https://doi.org/10.1016/j.clay.2005.08.008

[23] Krishnan, K.A. and Anirudhan, T.S. (2008) Kinetic and Equilibrium Modelling of Cobalt (II) Adsorption onto Bagasse Pith Based Sulphurised Activated Carbon. Chemical Engineering Journal, 137, 257-264. https://doi.org/10.1016/j.cej.2007.04.029

[24] McKay, G. (1996) Use of Adsorbents for the Removal of Pollutants from Wastewaters. CRC Press Inc., Tokyo.

[25] Girgis, B.S. and Ihsak, M.F. (1999) Activated Carbon from Cotton Stalks by Impregnation with Phosphoric Acid. Materials Letters, 39, 107-114. https://doi.org/10.1016/S0167-577X(98)00225-0

[26] Demirbaş, Ö., Karadağ, A., Alkan, M. and Doğan, M. (2008) Removal of Copper Ions from Aqueous Solutions by Hazelnut Shell. Journal of Hazardous Materials, 153, 677-684. https://doi.org/10.1016/j.jhazmat.2007.09.012

[27] Demirbas, A. (2008) Heavy Metals Adsorption onto Agro-Based Waste Materials: A Review. Journal of Hazardous Materials, 157, 220-229. https://doi.org/10.1016/j.jhazmat.2008.01.024

[28] Farahani, M. and Behbahaninia, A. (2014) Using Natural Adsorbents to Reduce Polycyclic Aromatic Hydrocarbons Contamination of Oily Wastewater. Journal of Biomedical and Environmental Sciences, 5, 274-281.

[29] Ho, Y.S. and McKay, G. (2000) The Kinetics of Sorption of Divalent Metal Ions onto Sphagnum Moss Peat. Water Research, 34, 735-742. 
[30] Poots, V.J.P., McKay, G. and Healy, J.J. (1978) Removal of Basic Dye from Effluent Using Wood as an Adsorbent. Journal of Water Pollution Control Federation, 50, 926-935.

[31] Al-Asheh, S. and Duvnjak, Z. (1997) Sorption of c Admium and Other Heavy Metals by Pine Bark. Journal of Hazardous Materials, 56, 35-51. https://doi.org/10.1016/S0304-3894(97)00040-X

[32] Low, K.S., Lee, C.K. and Leo, A.C. (1995) Removal of Metals from Electroplating Wastes Using Banana Pith. Bioresource Technology, 51, 227-231. https://doi.org/10.1016/0960-8524(94)00123-I

[33] Marshall, W.E. and Johns, M.M. (1996) Agricultural By-Products as Metal Adsorbents: Sorption Properties and Resistance to Mechanical Abrasion. Journal of Chemical Technology \& Biotechnology, 66, 192-198. https://doi.org/10.1002/(SICI)1097-4660(199606)66:2\%3C192::AID-JCTB489\%3E3. $\underline{0 . \mathrm{CO} ; 2-\mathrm{C}}$

[34] Wafwoyo, W., Seo, C.W. and Marshall, W.E. (1999) Utilization of Peanut Shells as Adsorbents for Selected Metals. Journal of Chemical Technology \& Biotechnology, 74, 1117-1121. https://doi.org/10.1002/(SICI)1097-4660(199911)74:11\%3C1117::AID-JCTB151\%3E 3.0.CO;2-R

[35] Cimino, G., Passerini, A. and Toscano, G. (2000) Removal of Toxic Cations and Cr(VI) from Aqueous Solution by Hazelnut Shell. Water Research, 34, 2955-2962. https://doi.org/10.1016/S0043-1354(00)00048-8

[36] Mishra, S.P., Tiwari, D. and Dubey, R.S. (1997) The Uptake Behavior of Rice (Jaya) Husk in the Removal of $\mathrm{Zn}$ (II) Ions: A Radiotracer Study. Applied Radiation and Isotopes, 48, 877-882. https://doi.org/10.1016/S0969-8043(97)00340-0

[37] Yu, B., Zhang, Y., Shukla, A., Shukla, S.S. and Dorris, K.L. (2001) The Removal of Heavy Metals from Aqueous Solutions by Sawdust Adsorption: Removal of Lead and Comparison of Its Adsorption with Copper. Journal of Hazardous Materials, 84, 83-94. https://doi.org/10.1016/S0304-3894(01)00198-4

[38] Balkose, D. and Baltacioglu, H. (1992) Adsorption of Heavy Metal Cations from Aqueous Solutions by Wool Fibers. Journal of Chemical Technology \& Biotechnology, 54, 393-397. https://doi.org/10.1002/jctb.280540414

[39] Azab, M.S. and Peterson, P.J. (1989) The Removal of Cadmium from Water by the Use of Biological Sorbents. Water Science and Technology, 21, 1705-1706.

[40] Zaggout, F.R. (2001) Removal of Copper from Water by Decaying Tamrix Gallica Leaves. Asian Journal of Chemistry, 13, 639-650.

[41] Luckey, T.D. and Venugopal, B. (1977) Metal Toxicity in Mammals. Plenum Press, New York.

[42] Chang, S.H., Teng, T.T. and Ismail, N. (2010) Extraction of Cu (II) from Aqueous Solutions by Vegetable Oil-Based Organic Solvents. Journal of Hazardous Materials, 181, 868-872. https://doi.org/10.1016/j.jhazmat.2010.05.093

[43] Guijuan, J.I., Weiwei, B.A.O., Guimei, G.A.O., Baichao, A.N. and Shucai, G.A.N. (2012) Removal of Cu (II) from Aqueous Solution Using a Novel Crosslinked Alumina-Chitosan Hybrid Adsorbent. Chinese Journal of Chemical Engineering, 20, 641-648. https://doi.org/10.1016/S1004-9541(11)60229-2

[44] Manahan, S.E. (1991) Environmental Chemistry. 5th Edition, Lewis Publishers, Chelsea.

[45] Larous, S. and Meniai, A.H. (2012) Removal of Copper (II) from Aqueous Solution by Agricultural By-Products-Sawdust. Energy Procedia, 18, 915-923. 
https://doi.org/10.1016/j.egypro.2012.05.106

[46] Reza, B.L., Hamid, R.Z. and Mohammad, E.B. (2014) Removal of Cu(II) Ions from Aqueous Solutions by Low-Cost Natural Hydroxyapatite/Chitosan Composite: Equilibrium, Kinetic and Thermodynamic Studies. Journal of the Taiwan Institute of Chemical Engineers, 45, 1642-1648. https://doi.org/10.1016/j.jtice.2013.11.009

[47] World Health Organization and United Nations Environment Programme (1995) Health Risks from Marine Pollution in the Mediterranean. Part VII. Evaluation of Health Risks from Chemically-Contaminated Seafood. World Health Organization Regional Office for Europe, Copenhagen.

[48] The Council of the European Communities (1982) Directive 82/176/EEC-On Pollution Caused by Certain Dangerous Substances Discharged into the Aquatic Environment of the Community. European Union, Brussels.

[49] Kurniawan, T.A., Chan, G.Y., Lo, W.H. and Babel, S. (2006) Comparisons of LowCost Adsorbents for Treating Wastewaters Laden with Heavy Metals. Science of the Total Environment, 366, 409-426. https://doi.org/10.1016/j.scitotenv.2005.10.001

[50] Bailey, S.E., Olin, T.J., Bricka, R.M. and Adrian, D.D. (1999) A Review of Potentially Low-Cost Sorbents for Heavy Metals. Water Research, 33, 2469-2479. https://doi.org/10.1016/S0043-1354(98)00475-8

[51] Hashem, A., Abdel-Halim, E.S., El-Tahlawy, K.F. and Hebeish, A. (2005) Enhancement of Adsorption of Co (II) and Ni (II) Ions onto Peanut Hulls though Esterification Using Citric Acid. Adsorption Science and Technology, 23, 367-380. https://doi.org/10.1260/026361705774355478

[52] Hashem, A., Akasha, R.A., Ghith, A. and Hussein, D.A. (2007) Adsorbent Based on Agricultural Wastes for Heavy Metal and Dye Removal: A Review. Energy Education Science and Technology, 19, 69-86.

[53] Food and Agriculture Organization of the United Nations (2011) FAO Statistics Division 2011, Sesame Seed. Food and Agriculture Organization of the United Nations, New York.

[54] Manal, A.M.H. (2013) Studies on Egyptian Sesame Seeds (Sesamum indicum L.) and Its Products. 3. Effect of Roasting Process on Gross Chemical Composition, Functional Properties, Antioxidative Components and Some Minerals of Defatted Sesame Seeds Meal (Sesamum indicum L.). World Journal of Dairy \& Food Sciences, 8, 51-57.

[55] Štefan, S. and Jan, P. (2005) Potential Application of Oilseeds as Sources of Antioxidants for Food Lipids-A Review. Czech Journal of Food, 23, 93-102.

[56] Michalak, A. (2006) Phenolic Compounds and Their Antioxidant Activity in Plants Growing under Heavy Metal Stress. Polish Journal of Environmental Studies, 15, 523-530.

[57] Sćiban, M., Klasnja, M. and Skrbić, B. (2006) Modified Softwood Sawdust as Adsorbent of Heavy Metal Ions from Water. Journal of Hazardous Materials, 136, 266271. https://doi.org/10.1016/j.jhazmat.2005.12.009

[58] Ojedokun, A.T. and Olugbenga, S.B. (2015) An Overview of Low Cost Adsorbents for Copper (II) Ions Removal. Journal of Biotechnology \& Biomaterials, 5, 175-177.

[59] Alyüz, B. and Veli, S. (2009) Kinetics and Equilibrium Studies for the Removal of Nickel and Zinc from Aqueous Solutions by Ion Exchange Resins. Journal of Hazardous Materials, 167, 482-488. https://doi.org/10.1016/j.jhazmat.2009.01.006

[60] Ramakrishna, G. and Susmita, M. (2010) Process Optimization of Adsorption of Cr (VI) on Activated Carbons Prepared from Plant Precursors by a Two-Level Full Factorial Design. Chemical Engineering Journal, 160, 99-107. 
https://doi.org/10.1016/j.cej.2010.03.015

[61] Hossain, M.A., Ngo, H.H., Guo, W.S. and Setiadi, T. (2012. Adsorption and Desorption of Copper (II) Ions onto Garden Grass. Bioresource Technology, 121, 386- 395. https://doi.org/10.1016/j.biortech.2012.06.119

[62] Oo, C., Osman, H., Fatinathan, S. and Zin, M. (2013) The Uptake of Copper (II) Ions by Chelating Schiff Base Derived from 4-Aminoantipyrine and 2-Methoxybenzaldehyde. International Journal of Non-Ferrous Metals, 2, 1-9. https://doi.org/10.4236/ijnm.2013.21001

[63] Leandro, V.A.G. and Laurent, F.G. (2009) Adsorption of Cu (II), Cd (II) and Pb (II) from Aqueous Single Metal Solutions by Succinylated Twice-Mercerized Sugarcane Bagasse Functionalized with Triethylenetetramine. Water Research, 43, 4479-4488. https://doi.org/10.1016/j.watres.2009.07.017

[64] Meena, A.K., Kiran, C.R. and Mishra, G.K. (2010) Removal of Heavy Metal Ions from Aqueous Solutions Using Chemically (Na2S) Treated Granular Activated Carbon as an Adsorbent. Journal of Scientific and Industrial Research, 69, 449-453.

[65] Zendelska, A., Golomeova, M., Blazev, K., Krstev, B., Golomeov, B. and Krstev, A. (2015) Adsorption of Copper Ions from Aqueous Solutions on Natural Zeolite. Environment Protection Engineering, 41, 17-36.

[66] Chuan, F.Z., Yu, R., Fang, F.W., Hong, L. and Yu, Y.C. (2016) Adsorption of Cu (II) from Aqueous Solutions by Ammoniated Cotton Fiber. Journal of Engineered Fibers and Fabrics, 11, 9-18.

[67] Pandey, P., Sambi, S.S., Sharma, S.K. and Singh, S. (2009) Batch Adsorption Studies for the Removal of $\mathrm{Cu}$ (II) Ions by ZeoliteNaX from Aqueous Stream. Proceedings of the World Congress on Engineering and Computer Science, San Francisco, 20-22 October 2009, 122-127.

[68] Belay, K. and Hayelom, A. (2014) Removal of Methyl Orange from Aqueous Solutions Using Thermally Treated Egg Shell (Locally Available and Low Cost Biosorbent). Chemistry of Materials, 6, 31-39.

[69] Srivastava, V.C., Mall, I.D. and Mishra, I.M. (2006) Equilibrium Modelling of Single and Binary Adsorption of Cadmium and Nickel onto Baggase Fly Ash. Journal of Chemical \& Engineering, 117, 79-91. https://doi.org/10.1016/j.cej.2005.11.021

[70] Achak, M., Hafidi, A., Ouazzani, N., Sayadic, S. and Mandi, L. (2009) Low Cost Biosorbent Banana Peel for the Removal of Phenolic Compounds from Olive Mill Wastewater: Kinetic and Equilibrium Studies. Journal of Hazardous Materials, 166, 117- 125. https://doi.org/10.1016/j.jhazmat.2008.11.036

[71] Hossain, M.A., Ngo, H.H., Guo, W.S. and Nguyen, T.V. (2012) Removal of Copper from Water by Adsorption onto Banana Peel as Bioadsorbent. International Journal of Geotechnique, Construction Materials and Environment, 2, 227-234. https://doi.org/10.21660/2012.4.3c

[72] Esposito, A., Pagnanelli, F., Lodi, A., Solisio, C. and Vegliò, F. (2001) Biosorption of Heavy Metals by Sphaerotilus natans. An Equilibrium Study at Different $\mathrm{pH}$ and Biomass Concentrations. Hydrometallurgy, 60, 129-141. https://doi.org/10.1016/S0304-386X(00)00195-X

[73] Babel, S. and Kurniawan, T.A. (2004) Cr (VI) Removal from Synthetic Wastewater Using Coconut Shell Charcoal and Commercial Activated Carbon Modified with Oxidizing Agents and/or Chitosan. Chemosphere, 54, 951-967. https://doi.org/10.1016/j.chemosphere.2003.10.001

[74] Mall, D.I., Srivastava, V.C. and Agarwal, N.K. (2006) Removal of Orange-G and Methyl Violet Dyes by Adsorption onto Bagasse Fly Ash-Kinetic Study and Equili- 
brium Isotherm Analyses. Dyes and Pigments, 69, 210-223.

https://doi.org/10.1016/j.dyepig.2005.03.013

[75] Ola, A. (2007) Kinetic and Isotherm Studies of Copper (II) Removal from Wastewater Using Various Adsorbents. Egyptian Journal of Aquatic Research, 33, 125-143.

[76] Vijayaraghavan, K., Teo, T.T., Balasubramanian, R. and Joshi, U.M. (2009) Application of Sargassum Biomass to Remove Heavy Metal Ions from Synthetic MultiMetal Solutions and Urban Storm Water Runoff. Journal of Hazardous Materials, 164, 1019-1023. https://doi.org/10.1016/j.jhazmat.2008.08.105

[77] Garg, V.K., Gupta, R., Yadav, A.B. and Kumar, R. (2003) Dye Removal from Aqueous Solution by Adsorption on Treated Sawdust. Bioresource Technology, 89, 121 - 124. https://doi.org/10.1016/S0960-8524(03)00058-0

[78] Karthikeyan, S., Balasubramanian, R. and Yer, C.S.P. (2007) Evaluation of the Marine Algae Ulva fasciata and Sargassum for the Biosorption of Cu (II) from Aqueous Solutions. Bioresource Technology, 98, 452-455.

https://doi.org/10.1016/j.biortech.2006.01.010

[79] Auphedeous, Y.D., Boansi, A.O. and Pedavoah, M.M. (2015) Reduction of Fluorine in Water Using Clay Mixed with Hydroxyapatite. International Journal of Clothing Science and Technology, 5, 45-55.

[80] Annadurai, G., Juang, R.S. and Lee, D.J. (2003) Adsorption of Heavy Metals from Water Using Banana and Orange Peels. Water Science and Technology, 47, 185190.

[81] Ameh, P.O. and Odoh, R. (2012) Iraqi Palm-Date as Adsorbent for Removal of $\mathrm{Pb}$ (II) and Ni (II) Ions from Aqueous Solution. International Journal of Modern Chemistry, 4, 11-18.

[82] Fourest, E. and Roux, J.C. (1992) Heavy Metal Biosorption by Fungal Mycelial ByProducts: Mechanisms and Influence of $\mathrm{pH}$. Applied Microbiology and Biotechno$\log$, 37, 399-403. https://doi.org/10.1007/BF00211001

[83] Babalola, J.O., Overah, L.C., Adesola, B., Vincent, O.O. and Olatunde, A. (2011) Kinetic, Equilibrium and Thermodynamic Studies on the Biosorption of Cd (II) from Aqueous Solutions by the Leaf Biomass of Calotropis procera 'Sodom Apple'. Journal of Applied Sciences and Environmental Management, 15, 607-615.

[84] El-Hassouni, H., Abdellaoui, D. and Bengueddour, R. (2013) Kinetic and Isotherm Studies of Cu (II) Removal From Aqueous Solution Using Gigartina acicularis Biomass. Environmental Earth Sciences, 3, 44-52.

[85] El-Hassouni, H., Abdellaoui, D., El-Hani, S. and Bengueddour, R. (2014) Biosorption of Cadmium (II) and Copper (II) from Aqueous Solution Using Red Alga (Osmundea pinnatifida) Biomass. Journal of Materials and Environmental Science, 5, 967-974.

[86] Unuabonah, E.I., Adebowale, K.O., Olu-Owolabi, B.I., Yang, L.Z. and Kong, L.X. (2008) Adsorption of Pb (II) and Cd (II) from Aqueous Solutions onto Sodium Tetraborate-Modified Kaolinite Clay: Equilibrium and Thermodynamic Studies. $H y-$ drometallurgy, 93, 1-9. https://doi.org/10.1016/j.hydromet.2008.02.009

[87] Olu-Owolabi, B.I., Diagboya, P.N. and Ebaddan, W.C. (2012) Mechanism of $\mathrm{Pb}^{2+}$ Removal from Aqueous Solution Using a Non Living Moss Biomass. Chemical Engineering Journal, 195-196, 270-275. https://doi.org/10.1016/j.cej.2012.05.004

[88] Taha, A.A., Ahmed, A.M., Abdel-Rahman, H.H., Abouzeid, F.M. and AbdelMaksoud, M.O. (2017) Removal of Nickel Ions by Adsorption on Nano Bentonite: Equilibrium, Kinetic and Thermodynamics. Journal of Dispersion Science and Technology, 38, 757-767. https://doi.org/10.1080/01932691.2016.1194211 
[89] Pons, M.P. and Fusté, C.M. (1993) Uranium Uptake by Immobilized Cells of Pseudomonas Strain EPS 5028. Applied Microbiology and Biotechnology, 39, 661-665. https://doi.org/10.1007/BF00205071

[90] Tumin, N.D., Chuah, A.L., Zawani, Z. and Abdul-Rashid, S. (2008) Adsorption of Copper from Aqueous Solution by Elais guineensis Kernel Activated Carbon. Journal of Engineering Science \& Technology, 3, 180-189.

[91] Yu, L.J., Shukla, S.S., Dorris, K.L., Shukla, A. and Margrave, J.L. (2003) Adsorption of Chromium from Aqueous Solutions by Maple Sawdust. Journal of Hazardous Materials, 100, 53-63. https://doi.org/10.1016/S0304-3894(03)00008-6

[92] Bhatti, I., Qureshi, K., Kazi, R.A. and Ansari, A.K. (2008) Preparation and Characterisation of Chemically Activated Almond Shells by Optimization of Adsorption of Chromium VI from Aqueous Solutions. International Journal of Chemical and Biomolecular Engineering, 1, 150-155.

[93] Azouaou, N., Belmedani, M., Mokaddem, H. and Sadaoui, Z. (2013) Adsorption of Lead from Aqueous Solution onto Untreated Orange Barks. Chemical Engineering Transactions, 32, 55-60.

[94] Yao, S., Sun, S., Wang, S. and Shi, Z. (2016) Adsorptive Removal of Lead Ion from Aqueous Solution by Activated Carbon/Iron Oxide Magnetic Composite. Indian Journal of Chemical Technology, 23, 146-152.

[95] Najim, T.S., Elais N.J. and Dawood, A.A. (2009) Adsorption of Copper and Iron Using Low Cost Material as Adsorbent. Journal of Chemistry, 6, 161-168.

[96] Barka, N., Abdennouri, M., Makhfouk, M.E. and Qourzal, S. (2013) Biosorption Characteristics of Cadmium and Lead onto Eco-Friendly Dried Cactus (Opuntia ficus indica) Cladodes. Journal of Environmental Chemical Engineering, 1, 144-149. https://doi.org/10.1016/j.jece.2013.04.008

[97] Pandey, P.K., Sharma, S.K. and Sambi, S.S. (2010) Kinetics and Equilibrium Study of Chromium Adsorption on ZeoliteNaX. International Journal of Environmental Science and Technology, 7, 395-404. https://doi.org/10.1007/BF03326149

[98] Martínez, M., Miralles, N., Hidalgo, S., Fiol, N., Villaescusa, I. and Poch, J. (2006) Removal of Lead and Cadmium from Aqueous Solution Using Grape Stalk Waste. Journal of Hazardous Materials, 133, 203-211. https://doi.org/10.1016/j.jhazmat.2005.10.030

[99] Zhang, X. and Wang, X. (2015) Adsorption and Desorption of Nickel (II) Ions from Aqueous Solution by a Lignocellulose/Montmorillonite Nanocomposite. PLoS One, 10, e0117077. https://doi.org/10.1371/journal.pone.0117077

[100]Ang, X.W., Sethu, V.S., Andresen, J.M. and Sivakumar, M. (2013) Copper (II) Ion Removal from Aqueous Solutions Using Biosorption Technology: Thermodynamic and SEM-EDX Studies. Clean Technologies and Environmental Policy, 15, 401-407. https://doi.org/10.1007/s10098-012-0523-0

[101]Aksu, Z. and Kutsal, T.A. (1991) A Bioseparation Process for Removing Pb (II) Ions from Wastewater by Using C. Vulgaris. Journal of Chemical Technology \& Biotechnology, 52, 108-118.

[102]Jnr, M.H. and Spiff, A.I. (2005) Effects of Temperature on the Sorption of $\mathrm{Pb}^{2+}$ and $\mathrm{Cd}^{2+}$ from Aqueous Solution by Caladium Bicolor (Wild Cocoyam) Biomass. Electronic Journal of Biotechnology, 8, 162-169.

https://doi.org/10.2225/vol8-issue2-fulltext-4

[103]Zhou, J.L. and Banks, C.J. (1993) Mechanism of Humic Acid Color Removal from Natural Waters by Fungal Biomass Biosorption. Chemosphere, 27, 607-620. https://doi.org/10.1016/0045-6535(93)90096-N 
[104]Karthik, V., Velan, M., Kumar, M.D. and Renganathan, S. (2009) Removal of Brill Red 5B from an Aqueous Solution Using Cicca acida Biomass. Canadian Journal of Chemistry, 87, 554-561. https://doi.org/10.1002/cjce.20188

[105]Shafqat, F., Bhatti, H.N., Hanif, M.A. and Zubair, A. (2008) Kinetic and Equilibrium Studies of Cr (III) and Cr (VI) Sorption from Aqueous Solution Using Rosa gruss an Teplitz (Red Rose) Waste Biomass. Journal of the Chilean Chemical Society, 53, 1667-1672. https://doi.org/10.4067/S0717-97072008000400006

[106]Areco, M.M. and Afonso, M.S. (2010) Copper, Zinc, Cadmium and Lead Biosorption by Gymnogongrus torulosus. Thermodynamics and Kinetics Studies. Colloids and Surfaces B: Biointerfaces, 81, 620-628.

https://doi.org/10.1016/j.colsurfb.2010.08.014

[107]Alpat, Ş., Alpat, S.K., Çadirci, B.H., Özbayrak, Ö. and Yasa, İ. (2010) Effects of Biosorption Parameter: Kinetics, Isotherm and Thermodynamics for Ni (II) Biosorption from Aqueous Solution by Circinella. Electronic Journal of Biotechnology, 13, $1-19$.

[108]Aksu, Z. and İşoğlu, İ.A. (2005) Removal of Copper (II) Ions from Aqueous Solution by Biosorption onto Agricultural Waste Sugar Beet Pulp. Process Biochemistry, 40, 3031-3044. https://doi.org/10.1016/j.procbio.2005.02.004

[109]Aregawi, B.H. and Mengistie, A.A. (2013) Removal of Ni (II) from Aqueous Solution Using Leaf, Bark and Seed of Moringa stenopetala Adsorbents. Bulletin of the Chemical Society of Ethiopia, 27, 35-47.

[110]Anwar, J., Shafique, U., Zaman, W., Salman, M., Dar, A. and Anwar, S. (2010) Removal of $\mathrm{Pb}$ (II) and $\mathrm{Cd}$ (II) from Water by Adsorption on Peels of Banana. Bioresource Technology, 101, 1752-1755. https://doi.org/10.1016/j.biortech.2009.10.021

[111]Wang, Y., Wang, X., Wang, X., Liu, M., Wu, Z., Yang, L., Xia, S. and Zhao, J. (2013) Adsorption of $\mathrm{Pb}$ (II) from Aqueous Solution to Ni-Doped Bamboo Charcoal. Journal of Industrial and Engineering Chemistry, 19, 353-359.

https://doi.org/10.1016/j.jiec.2012.08.024

[112]Njoku, V.O., Islam, M.A., Asifd, M. and Hameed, B.H. (2014) Preparation of Mesoporous Activated Carbon from Coconut Frond for the Adsorption of Carbofuran Insecticide. Journal of Analytical and Applied Pyrolysis, 110, 172-180. https://doi.org/10.1016/j.jaap.2014.08.020

[113]Tran, H.N., You, S.J. and Chao, H.P. (2016) Thermodynamic Parameters of Cadmium Adsorption onto Orange Peel Calculated from Various Methods: A Comparison Study. Journal of Environmental Chemical Engineering, 4, 2671-2682. https://doi.org/10.1016/j.jece.2016.05.009

[114]Bulut, Y. and Tez, Z. (2007) Adsorption Studies on Ground Shells of Hazelnut and Almond. Journal of Hazardous Materials, 149, 35-41. https://doi.org/10.1016/j.jhazmat.2007.03.044

[115]Liu, L., Liu, J., Li, H., Zhang, H., Liu, J. and Zhang, H. (2012) Equilibrium, Kinetic, and Thermodynamic Studies of Lead (II) Biosorption on Sesame Leaf. BioResources, 7, 3555-3572.

[116]Pednekar, P.A. and Raman, B. (2013) The FT-IR Spectrometric Studies of Vibrational Bands of Semecarpus anacardiumlinn. F. Leaf, Stem Powder and Extracts. Asian Journal of Pharmaceutical and Clinical Research, 6, 159-198.

[117]Thatte, C.S., Rathnam, M.V. and Pise, A.C. (2014) Chitosan-Based Schiff Base-Metal Complexes ( $\mathrm{Mn}, \mathrm{Cu}, \mathrm{Co})$ as Heterogeneous, New Catalysts for the $\beta$-Isophorone Oxidation. Journal of Chemical Sciences, 126, 727-737. https://doi.org/10.1007/s12039-014-0601-4

[118]Kannan, S. (2014) FT-IR and EDS Analysis of the Seaweeds Sargassum wightii 
(Brown Algae) and Gracilaria corticata (Red Algae). International Journal of Current Microbiology and Applied Sciences, 3, 341-351.

[119]Sanati, M. and Andersson, A. (1993) DRIFT Study of the Oxidation and the Ammoxidation of Toluene over a TiO2, (B)-Supported Vanadia Catalyst. Journal of Molecular Catalysis A: Chemical, 81, 51-62. https://doi.org/10.1016/0304-5102(93)80022-M

[120]Chen, Y., Zou, C., Mastalerz, M., Hu, S., Gasaway, C. and Tao, X. (2015) Applications of Micro-Fourier Transform Infrared Spectroscopy (FTIR) in the Geological Sciences-A Review. International Journal of Molecular Sciences, 16, 30223-30250. https://doi.org/10.3390/ijms161226227

[121]Sharma, B.K. (2005) Infrared Spectroscopy. In: Instrumental Methods of Chemical Analysis, Goel Publishing House, Krishna Prakashan Media Ltd., Meerut, 193-333.

[122]Ravishankara, D.K. and Chandrashekara, P.G. (2012) Synthesis of Some Novel Benzimidazole Derivatives and Its Biological Evaluation. European Journal of Chemistry, 3, 359-362. https://doi.org/10.5155/eurjchem.3.3.359-362.607

[123]Hussein, F.H., Abbas, A.F. and Hussein, M.A. (2016) Synthesis and Characterization of Some New Heterocyclic Compounds Derived from 1,3-Bis(4-Nitrophenyl) Prop-2-en-1-One. Research Journal of Pharmaceutical, Biological and Chemical Sciences, 7, 1837-1841.

[124]Han, R., Zhang, L., Song, C., Zhang, M., Zhu, H. and Zhang, L. (2010) Characterization of Modified Wheat Straw, Kinetic and Equilibrium Study about Copper Ion and Methylene Blue Adsorption in Batch Mode. Carbohydrate Polymers, 79, 1140 1149. https://doi.org/10.1016/j.carbpol.2009.10.054

[125]Harder, P., Grunze, M. and Dahint, R. (1998) Molecular Conformation in Oligo (Ethylene Glycol)-Terminated Self-Assembled Monolayers on Gold and Silver Surfaces Determines Their Ability to Resist Protein Adsorption. Journal of Physical Chemistry B, 102, 426-436. https://doi.org/10.1021/jp972635z

[126]Gunasekaran, S., Natarajan, R.K. and Kala, A. (2007) FT-IR Spectra and Mechanical Strength Analysis of Some Selected Rubber Derivatives. Spectrochimica Acta, Part A: Molecular and Biomolecular Spectroscopy, 68, 323-330. https://doi.org/10.1016/j.saa.2006.11.039

[127]Sharma, M., Crosbie, J.C., Puskar, L. and Rogers, P.A.W. (2013) Microbeam-Irradiated Tumour Tissue Possesses a Different Infrared Absorbance Profile Compared to Broad Beam and Sham-Irradiated Tissue. International Journal of Radiation Biology, 89, 79-87. https://doi.org/10.3109/09553002.2012.721052

[128]Ferrer, A., Alciaturi, C., Faneite, A. and Ríos, J. (2016) Analyses of Biomass Fibers by XRD. In: Jr, S.V., Ed., FT-IR, and NIR. In Analytical Techniques and Methods for Biomass, Springer, Cham, 45-83. https://doi.org/10.1007/978-3-319-41414-0_3

[129]Pandey, K.K. and Pitman, A.J. (2004) Examination of the Lignin Content in S Softwood and a Hardwood Decayed by a Brown-Rot Fungus with the Acetyl Bromide Method and Fourier Transform Infrared Spectroscopy. Journal of Polymer Science Part A: Polymer Chemistry, 42, 2340-2346. https://doi.org/10.1002/pola.20071

[130]Smidt, E. and Meissl, K. (2007) The Applicability of Fourier Transform Infrared (FT-IR) Spectroscopy in Waste Management. Waste Management, 27, 268-276. https://doi.org/10.1016/j.wasman.2006.01.016

[131]Pandey, K.K., Hughes, M. and Vuorinen, T. (2010) Dimensional Stability, UV Resistance, and Static Mechanical Properties of Scots Pine Chemically Modified with Alkylene epoxides. BioResources, 5, 598-615.

[132]Anastopoulos, I., Panagiotou, M., Ehaliotis, C., Tarantilis, P.A. and Massas, I. (2015) 
$\mathrm{NaOH}$ Pretreatment of Compost Derived from Olive Tree Pruning Waste Biomass Greatly Improves Biosorbent Characteristics for the Removal of $\mathrm{Pb}^{2+}$ and $\mathrm{Ni}^{2+}$ from Aqueous Solutions. International Society of Chemical Ecology, 31, 724-740. https://doi.org/10.1080/02757540.2015.1095294

[133]Via, B.K., Fasina, O. and Pan. H. (2011) Assessment of Pine Biomass Density through Mid-Infrared Spectroscopy and Multivariate Modeling. BioResources, 6, 807 822.

[134]Ozgenc, O., Okan, O.T., Yildiz, U.C. and Deniz, I. (2013) Wood Surface Protection against Artificial Weathering with Vegetable Seed Oils. BioResources, 8, 6242-6262. https://doi.org/10.15376/biores.8.4.6242-6262

[135]Cheraghi, E., Ameri, E. and Moheb, A. (2015) Adsorption of Cadmium Ions from Aqueous Solutions Using Sesame as a Low-Cost Biosorbent: Kinetics and Equilibrium Studies. International Journal of Environmental Science and Technology, 12, 2579-2592. https://doi.org/10.1007/s13762-015-0812-3

[136]Cheraghi, E., Ameri, E. and Moheb, A. (2016) Continuous Biosorption of Cd (II) Ions from Aqueous Solutions by Sesame Waste: Thermodynamics and Fixed-Bed Column Studies. Desalination and Water Treatment, 57, 6936-6949. https://doi.org/10.1080/19443994.2015.1012744

[137]Janakiraman, N. and Johnson, M. (2015) Functional Groups of Tree Ferns (Cyathea) Using FT-IR: Chemotaxonomic Implications. Romanian Journal of Biophysics, 25, 131-141.

[138]Tappert, R., Wolfe, A.P., McKellar, R.C., Tappert, M.C. and Muehlenbachs, K. (2011) Characterizing Modern and Fossil Gymnosperm Exudates Using MicroFourier Transform Infrared Spectroscopy. International Journal of Biological Sciences, 172, 120-138.

[139]Pavia, D.L., Lampman, G.M., Kriz, G.S. and Vyvyan, J.R. (2009) Infrared Spectroscopy. In: Introduction to Spectroscopy, Cengage Learning, Washington DC, 15-30.

[140]Aladdin, N.A., Jamal, J.A., Talip, N., Hamsani, N.A.M., Rahman, M.R.A., Sabandar, C.W., Muhammad, K., Husain, K. and Jalil, J. (2016) Comparative Study of Three Marantodes pumilum Varieties by Microscopy, Spectroscopy and Chromatography. Brazilian Journal of Pharmacognosy, 26, 1-14. https://doi.org/10.1016/j.bjp.2015.10.002

[141]Subhan, M.A., Sarker, P. and Ahmed, T. (2014) Analysis of Kidney and Gall Stones of Patients from North-East Bangladesh by FTIR. Journal of Scientific Research, 6, 553-561. https://doi.org/10.3329/jsr.v6i3.16721

[142]Ngah, W.S.W. and Hanafiah, M.A.K.M. (2008) Biosorption of Copper Ions from Dilute Aqueous Solutions on Base Treated Rubber (Hevea brasiliensis) Leaves Powder: Kinetics, Isotherm, and Biosorption Mechanisms. Journal of Environmental Sciences-China, 20, 1168-1176. https://doi.org/10.1016/S1001-0742(08)62205-6

[143]Chen, H. and Wang, A.Q. (2009) Adsorption Characteristics of Cu (II) from Aqueous Solution onto Poly (Acrylamide)/Attapulgite Composite. Journal of Hazardous Materials, 165, 223-231. https://doi.org/10.1016/j.jhazmat.2008.09.097

[144]Lasheen, M.R., Ammar, N.S. and Ibrahim, H.S. (2012) Adsorption/Desorption of Cd (II), $\mathrm{Cu}$ (II) and $\mathrm{Pb}$ (II) Using Chemically Modified Orange Peel: Equilibrium and Kinetic Studies. Solid State Sciences, 14, 202-210. https://doi.org/10.1016/j.solidstatesciences.2011.11.029

[145]Dağdelen, S., Acemioğlu, B., Baran, E. and Koçer, O. (2014) Removal of Remozal Brilliant Blue R from Aqueous Solution by Pirina Pretreated with Nitric Acid and Commercial Activated Carbon. Water, Air, \& Soil Pollution, 225, 1-15. 
https://doi.org/10.1007/s11270-014-1899-8

[146]Bilgili, A.S. (2006) Adsorption of 4-Chlorophenol from Aqueous Solutions by Xad-4 Resin: Isotherm, Kinetic, and Thermodynamic Analysis. Journal of Hazardous Materials, 137, 157-164. https://doi.org/10.1016/j.jhazmat.2006.01.005

[147]You, L., Lu, F., Song, L., Yin, Y. and Zhang, Q. (2015) Enhanced Decolorization of Aqueous Dye Solutions by a High Quality Copolymer Flocculant. Royal Society of Chemistry, 5, 64711-64723. https://doi.org/10.1039/c5ra07662e

[148]Gaballah, I. and KIlbertus, G. (1998) Recovery of Heavy Metal Ions through Decontamination of Synthetic Solutions and Industrial Effluents Using Modified Barks. Journal of Geochemical Exploration, 62, 241-286. https://doi.org/10.1016/S0375-6742(97)00068-X

[149]Hema, M. and Arivoli, S. (2008) Adsorption Kinetics and Thermodynamics of Malachite Green Dye unto Acid Activated Low Cost Carbon. Journal of Applied Sciences and Environmental Management, 12, 43-51.

[150]Kannan, A. and Thambidurai, S. (2008) Comparative Studies on the Removal of Nickel (II) from Aqueous Solution by Using Carbon Derived from Palmyra Palm Fruit Seeds and Commercial Activated Carbon. International Journal of Science and Technology, 1, 93-107.

[151]El-Haddad, M. (2016) Removal of Basic Fuchsin Dye from Water Using Mussel Shell Biomass Waste as an Adsorbent: Equilibrium, Kinetics, and Thermodynamics. Journal of Taibah University for Science, 10, 664-674. https://doi.org/10.1016/j.jtusci.2015.08.007

[152]Langmuir, I. (1916) The Constitution and Fundamental Properties of Solids and Liquids. Journal of the American Chemical Society, 38, 2221-2295. https://doi.org/10.1021/ja02268a002

[153]Hall, K.R., Eagleton, L.C., Acrivos, A. and Vermeulen, T. (1966) Pore and Solid-Diffusion Kinetics in Fixed-Bed Adsorption under Constant-Pattern Conditions. Industrial \& Engineering Chemistry Research, 5, 212-223.

[154]Karapinar, N. and Donat, R. (2009) Adsorption Behavior of $\mathrm{Cu}^{2+}$ and $\mathrm{Cd}^{2+}$ onto Natural Bentonite. Desalination, 249, 123-129.

https://doi.org/10.1016/j.desal.2008.12.046

[155]Halnor, S., Farooqui, M. and Ubale, M. (2013) Removal of Copper (II) from Aqueous Solution and Waste Water by Prosopis juliflora Leaf Powder by Adsorption. International Journal of Application or Innovation in Engineering \& Management, 2, 125-131. http://www.ijaiem.org/Volume2Issue3/IJAIEM-2013-03-14-028.pdf

[156]Igwe, J.C. and Abia. A.A. (2007) Adsorption Kinetics and Intra-Particulate Diffusivities for Bioremediation of Co (II), Fe (II) and Cu (II) Ions from Waste Water Using Modified and Unmodified Maize Cob. International Journal of Physics-Science, 2, 119-127.

[157]Geçgel, Ü., Kocabiyık, B. and Üner, O. (2015) Adsorptive Removal of Methylene Blue from Aqueous Solution by the Activated Carbon Obtained from the Fruit of Catalpa Bignonioides. Water, Air, \& Soil Pollution, 226, 1-14.

https://doi.org/10.1007/s11270-015-2513-4

[158]Li, Q., Yue, Q.Y., Sun, H.J., Su, Y. and Gao, B.Y. (2010) A Comparative Study on the Properties, Mechanisms and Process Designs for the Adsorption of Non-Ionic or Anionic Dyes onto Cationic-Polymer/Bentonite. Journal of Environmental Management, 91, 1601-1611. https://doi.org/10.1016/j.jenvman.2010.03.001

[159]Freundlich, H.M.F. (1906) Over the Adsorption in Solution. Journal of Physical Chemistry, 57, 385-470. 
[160]Friess, W. (1998) Collagen-Biomaterial for Drug Delivery. European Journal of Pharmaceutics and Biopharmaceutics, 45, 113-136. https://doi.org/10.1016/S0939-6411(98)00017-4

[161]Qiang, T., Bu, Q., Ren, L. and Wang, X. (2014) Adsorption Behaviors of Cr (III) on Carboxylated Collagen Fiber. Journal of Applied Polymer Science, 131, 1-6. https://doi.org/10.1002/app.40285

[162]Hasany, S.M., Saeed, M.M. and Ahmed, M. (2002) Sorption and Thermodynamic Behavior of Zinc (II)-Thiocyanate Complexes onto Polyurethane Foam from Acidic Solutions. Journal of Radioanalytical and Nuclear Chemistry, 252, 477-484. https://doi.org/10.1023/A:1015890317697

[163]Ngah, W.S.W. and Fatinathan, S. (2010) Adsorption Characterization of $\mathrm{Pb}$ (II) and $\mathrm{Cu}$ (II) Ions onto Chitosan-Tripolyphosphate Beads: Kinetic, Equilibrium and Thermodynamic Studies. Journal of Environmental Management, 91, 958-969. https://doi.org/10.1016/j.jenvman.2009.12.003

[164]Dubinin, M.M. and Radushkevich, L.V. (1947) The Equation of the Characteristic Curve of the Activated Charcoal. Proceedings of the Union of Soviet Socialist Republics Academy of Sciences, 55, 331-337.

[165]Ozcan, A.S., Erdem, B. and Ozcan, A. (2005) Adsorption of Acid Blue 193 from Aqueous Solutions onto BTMA-Bentonite. Colloids and Surfaces A: Physicochemical and Engineering Aspects, 266, 73-81. https://doi.org/10.1016/j.colsurfa.2005.06.001

[166]Hobson, J.P. (1969) Physical Adsorption Isotherms Extending from Ultrahigh Vacuum to Vapor Pressure. Journal of Physical Chemistry, 73, 2720-2727. https://doi.org/10.1021/j100842a045

[167]Hasany, S.M. and Chaudhary, M.H. (1996) Sorption Potential of Hare River Sand for the Removal of Antimony from Acidic Aqueous Solution. Applied Radiation and Isotopes, 47, 467-471. https://doi.org/10.1016/0969-8043(95)00310-X

[168]Dubey, S.S. and Gupta, R.K. (2005) Removal Behavior of Babool Bark (Acacia Nilotica) for Submicro Concentrations of $\mathrm{Hg}^{2+}$ from Aqueous Solutions: A Radiotracer Study. Separation and Purification Technology, 41, 21-28. https://doi.org/10.1016/j.seppur.2004.03.012

[169]Koyuncu, H. and Kul, A.R. (2014) An Investigation of Cu (II) Adsorption by Native and Activated Bentonite: Kinetic, Equilibrium and Thermodynamic Study. The Journal of Environmental Chemical Engineering, 2, 1722-1730. https://doi.org/10.1016/j.jece.2014.06.012

[170]Kundu, S. and Gupta, A.K. (2006) Arsenic Adsorption onto Iron Oxide-Coated Cement (IOCC): Regression Analysis of Equilibrium Data with Several Isotherm Models and Their Optimization. Chemical Engineering Journal, 122, 93-106. https://doi.org/10.1016/j.cej.2006.06.002

[171]Dang, V.B.H., Doan, H.D., Dang-Vu, T. and Lohi, A. (2009) Equilibrium and Kinetics of Biosorption of Cadmium (II) and Copper (II) Ions by Wheat Straw. Bioresource Technology, 100, 211-219. https://doi.org/10.1016/j.biortech.2008.05.031

[172]Farooq, U., Kozinski, J.A., Khan, M.A. and Athar, M. (2010) Biosorption of Heavy Metal Ions Using Wheat Based Biosorbents-A Review of the Recent Literature. Bioresource Technology, 101, 5043-5053. https://doi.org/10.1016/j.biortech.2010.02.030

[173]Abasi, C.Y., Abia, A.A. and Igwe, J.C. (2011) Adsorption of Iron (III), Lead (II) and Cadmium (II) Ions by Unmodified Raphia Palm (Raphia hookeri) Fruit Endocarp. Environmental Research, 5, 104-113. https://doi.org/10.3923/erj.2011.104.113

[174]Cozmuta, L.M., Cozmuta, A.M., Peter, A., Nicula, C., Nsimba, E.B. and Tutu, H. 
(2012) The Influence of $\mathrm{pH}$ on the Adsorption of Lead by Na-Clinoptilolite: Kinetic and Equilibrium Studies. Water $S A, 38,269-278$.

https://doi.org/10.4314/wsa.v38i2.13

[175]Li, H., Xiao, D., He, H., Lin, R. and Zuo, P. (2013) Adsorption Behavior and Adsorption Mechanism of $\mathrm{Cu}$ (II) Ions on Amino-Functionalized Magnetic Nanoparticles. Transactions of Nonferrous Metals Society of China, 23, 2657-2665. https://doi.org/10.1016/S1003-6326(13)62782-X

[176]Pehlivan, E., Cetin, S. and Yanik, B.H. (2006) Equilibrium Studies for the Sorption of Zinc and Copper from Aqueous Solutions Using Sugar Beet Pulp and Fly Ash. Journal of Hazardous Materials, 135, 193-199. https://doi.org/10.1016/j.jhazmat.2005.11.049

[177]Villaescusa, I., Fiol, N., Martínez, M., Miralles, N., Poch, J. and Serarols, J. (2004) Removal of Copper and Nickel Ions from Aqueous Solutions by Grape Stalks Wastes. Water Research, 38, 992-1002. https://doi.org/10.1016/j.watres.2003.10.040

[178]El-Ashtoukhy, E.S.Z., Amin, N.K. and Abdelwahab, O. (2008) Removal of Lead (II) and Copper (II) from Aqueous Solution Using Pomegranate Peel as a New Adsorbent. Desalination, 223, 162-173. https://doi.org/10.1016/j.desal.2007.01.206

[179]Onundi, Y.B., Mamun, A.A., Al-Khatib, M.F. and Ahmed Y.M. (2010) Adsorption of Copper, Nickel and Lead Ions from Synthetic Semiconductor Industrial Wastewater by Shell Activated Carbon. Environmental Science \& Technology, 7, 751-758. https://doi.org/10.1007/bf03326184

[180]Karabulut, S., Karabakan, A., Denizli, A. and Yürüm, Y. (2000) Batch Removal of Copper (II) and Zinc (II) from Aqueous Solutions with Low-Rank Turkish Coals. Separation and Purification Technology, 18, 177-184. https://doi.org/10.1016/S1383-5866(99)00067-2

[181]Yu, B., Zhang, Y., Shukla, A., Shukla, S.S. and Dorris, K.L. (2000) The Removal of Heavy Metal from Aqueous Solutions by Sawdust Adsorption-Removal of Copper. Journal of Hazardous Materials, 80, 33-42. https://doi.org/10.1016/S0304-3894(00)00278-8

[182]Gupta, V.K. and Ali, I. (2000) Utilization of Bagasse Fly Ash (a Sugar Industry Waste) for the Removal of Copper and Zinc from Wastewater. Separation and Purification Technology, 18, 131-140. https://doi.org/10.1016/S1383-5866(99)00058-1

[183]Kalavathy, M.H. and Miranda, L.R. (2010) Comparison of Copper Adsorption from Aqueous Solution Using Modified and Unmodified Hevea brasiliensis Saw Dust. Desalination, 255, 165-174. https://doi.org/10.1016/j.desal.2009.12.028

[184] Meunier, N., Laroulandie, J., Blais, J.F. and Tyagi, R.D. (2003) Cocoa Shells for Heavy Metal Removal from Acidic Solutions. Bioresource Technology, 90, 255-263. https://doi.org/10.1016/S0960-8524(03)00129-9

[185]Habib, A., Islam, N., Islam, A. and Shafiqul-Alam, A.M. (2007) Removal of Copper from Aqueous Solution Using Orange Peel, Sawdust and Bagasse. Pakistan Journal of Analytical \& Environmental Chemistry, 8, 21-25.

[186] Aydin, H., Bulut, Y. and Yerlikaya, C. (2008) Removal of Copper (II) from Aqueous Solution by Adsorption onto Low-Cost Adsorbents. Journal of Environmental Management, 87, 37-45. https://doi.org/10.1016/j.jenvman.2007.01.005

[187]Šćiban, M. and Klašnja, M. (2004) Wood Sawdust and Wood Originate Materials as Adsorbents for Heavy Metal Ions. European Journal of Wood and Wood Products, 62, 69-73. https://doi.org/10.1007/s00107-003-0449-7

[188]Altun, T. and Pehlivan, E. (2007) Removal of Copper (II) Ions from Aqueous Solutions by Walnut-, Hazelnut- and Almond-Shells. CLEAN-Soil, Air, Water, 35, 601- 
606. https://doi.org/10.1002/clen.200700046

[189]Putra, W.P., Kamari, A., Yusoff, S.N.M., Ishak, C.F., Mohamed, A., Hashim, N. and Isa, I.M. (2014) Biosorption of $\mathrm{Cu}$ (II), $\mathrm{Pb}$ (II) and $\mathrm{Zn}$ (II) Ions from Aqueous Solutions Using Selected Waste Materials: Adsorption and Characterisation Studies. American Journal of Applied Sciences, 4, 25-35.

[190]Ahamed, A.J. and Begum, A.S. (2012) Adsorption of Copper from Aqueous Solution Using Low-Cost Adsorbent. Archives of Applied Science Research, 4, 1532-1539.

[191]Shukla, S.R. and Pai, R.S. (2005) Adsorption of Cu (II), Ni (II) and Zn (II) on Modified Jute Fibres. Bioresource Technology, 96, 1430-1438.

https://doi.org/10.1016/j.biortech.2004.12.010

[192]Shukla, S.R. and Pai, R.S. (2005) Adsorption of Cu (II), Ni (II) and Zn (II) on Dye Loaded Groundnut Shells and Sawdust. Separation and Purification Technology, 43, 1-8. https://doi.org/10.1016/j.seppur.2004.09.003

[193] Kalavathy, M.H., Karthikeyan, T., Rajgopal, S. and Miranda, L.R. (2005) Kinetic and Isotherm Studies of $\mathrm{Cu}$ (II) Adsorption onto $\mathrm{H}_{3} \mathrm{PO}_{4}$-Activated Rubber Wood Sawdust. Journal of Colloid and Interface Science, 292, 354-362.

https://doi.org/10.1016/j.jcis.2005.05.087

[194]Paulino, A.G., Cunha, A.J.D., Alfaya, R.V.D.S. and Alfaya, A.A.D.S. (2014) Chemically Modified Natural Cotton Fiber: A Low-Cost Biosorbent for the Removal of the $\mathrm{Cu}$ (II), Zn (II), Cd (II), and Pb (II) from Natural Water. Desalination and Water Treatment, 52, 4223-4233. https://doi.org/10.1080/19443994.2013.804451

[195]Cao, X., Ma, L.Q., Rhue, D.R. and Appel, C.S. (2004) Mechanisms of Lead, Copper, and Zinc Retention by Phosphate Rock. Environmental Pollution, 131, 435-444. https://doi.org/10.1016/j.envpol.2004.03.003

[196]Reddad, Z., Gerente, C., Andres, Y. and Cloirec, P. (2002) Adsorption of Several Metal Ions onto a Low-Cost Biosorbent: Kinetic and Equilibrium Studies. Environmental Science \& Technology, 36, 2067-2073. https://doi.org/10.1021/es0102989

[197]Basci, N., Kocadagistan, E. and Kocadagistan, B. (2004) Biosorption of Copper (II) from Aqueous Solutions by Wheat Shell. Desalination, 164, 135-140.

https://doi.org/10.1016/S0011-9164(04)00172-9

[198]Brown, P., Jefcoat, I.A., Parrish, D., Gill, S. and Graham, E. (2000) Evaluation of the Adsorptive Capacity of Peanut Hull Pellets for Heavy Metals in Solution. Advances in Environmental Research, 4, 19-29. https://doi.org/10.1016/S1093-0191(00)00004-6

[199]Çay, S., Uyanik, A. and Ozasik, A. (2004) Single and Binary Component Adsorption of Copper (II) and Cadmium (II) from Aqueous Solutions Using Tea-Industry Waste. Separation \& Purification Technology, 38, 273-280. https://doi.org/10.1016/j.seppur.2003.12.003

[200]Ngah, W.S.W. and Hanafiah, M.A.K.M. (2008) Adsorption of Copper on Rubber (Hevea brasiliensis) Leaf Powder: Kinetic, Equilibrium and Thermodynamic Studies. Biochemical Engineering Journal, 39, 521-530. https://doi.org/10.1016/j.bej.2007.11.006

[201]Shukla, P.M. and Shukla, S.R. (2013) Biosorption of Cu (II), Pb (II), Ni (II), and Fe (II) on Alkali Treated Coir Fibers. Separation Science and Technology, 48, 421-428. https://doi.org/10.1080/01496395.2012.691933

[202]Al-Asheh, S., Banat, F., Al-Omari, R. and Duvnjak, Z. (2000) Predictions of Binary Sorption Isotherms for the Sorption of Heavy Metals by Pine Bark Using Single Isotherm Data. Chemosphere, 41, 659-665.

https://doi.org/10.1016/S0045-6535(99)00497-X 
[203]Rahman, M.S. and Islam, M.R. (2009) Effects of pH on Isotherms Modeling for Cu (II) Ions Adsorption Using Maple Wood Sawdust. Chemical Engineering Journal, 149, 273-280. https://doi.org/10.1016/j.cej.2008.11.029

[204]Lee, S.H. and Yang, J.W. (1997) Removal of Copper in Aqueous Solution by Apple Wastes. Separation Science and Technology, 32, 1371-1387. https://doi.org/10.1080/01496399708000966

[205]Sekomo, C.B., Rousseau, D.P.L. and Lens, P.N.L. (2012) Use of Gisenyi Volcanic Rock for Adsorptive Removal of Cd (II), Cu (II), Pb (II), and Zn (II) from Wastewater. Water, Air, \& Soil Pollution, 223, 533-547. https://doi.org/10.1007/s11270-011-0880-z

[206]Sulaiman, O., Amini, M.H.M., Rafatullah, M., Hashim, R. and Ahmad, A. (2010) Adsorption Equilibrium and Thermodynamic Studies of Copper (II) Ions from Aqueous Solutions by Oil Palm Leaves. International Journal of Chemical Reactor Engineering, 8, A108. https://doi.org/10.2202/1542-6580.2350

[207]Ozsoy, H.D. and Kumbur, H. (2006) Adsorption of Cu (II) Ions on Cotton Boll. Journal of Hazardous Materials, 136, 911-916. https://doi.org/10.1016/j.jhazmat.2006.01.035

[208]Ho, Y.S. (2003) Removal of Copper Ions from Aqueous Solution by Tree Fern. Water Research, 37, 2323-2330. https://doi.org/10.1016/S0043-1354(03)00002-2

[209]Veli, S. and Alyüz, B. (2007) Adsorption of Copper and Zinc from Aqueous Solutions by Using Natural Clay. Journal of Hazardous Materials, 149, 226-233. https://doi.org/10.1016/j.jhazmat.2007.04.109

[210]Lagergren, S. (1898) About the Theory of So-Called Adsorption of Soluble Substance. Kungliga Svenska Vetenskapsakademiens. Handlingar, 24, 1-39.

[211]Ho, Y.S. (2004) Citation Review of Lagergren Kinetic Rate Equation on Adsorption Reaction. Scientometrics, 59, 171-177. https://doi.org/10.1023/B:SCIE.0000013305.99473.cf

[212]Ünlü, N. and Ersoz, M. (2006) Adsorption Characteristics of Heavy Metal Ions onto a Low Cost Biopolymeric Sorbent from Aqueous Solutions. Journal of Hazardous Materials, 136, 272-280. https://doi.org/10.1016/j.jhazmat.2005.12.013

[213]Crini, G. and Badot, P.M. (2008) Application of Chitosan, a Natural Aminopolysaccharide, for Dye Removal from Aqueous Solutions by Adsorption Processes Using Batch Studies: A Review of Recent Literature. Progress in Polymer Science, 33, 399-447. https://doi.org/10.1016/j.progpolymsci.2007.11.001

[214]Ho, Y.S. and McKay, G. (1998) Sorption of Dye from Aqueous Solution by Peat. Chemical Engineering Journal, 70, 115-124. https://doi.org/10.1016/S0923-0467(98)00076-1

[215]Ho, Y.S. and McKay, G. (1999) Pseudo-Second Order Model for Sorption Processes. Process Biochemistry, 34, 451-465. https://doi.org/10.1016/S0032-9592(98)00112-5

[216]McKay, G. (2001) Solution to the Homogeneous Surface Diffusion Model for Batch Adsorption Systems Using Orthogonal Collocation. Chemical Engineering Journal, 81, 213-221. https://doi.org/10.1016/S1385-8947(00)00191-1

[217]Akretche, D.E. (2011) Metals Removal from Industrial Effluents. In: Coca-Prados, J. and Gutierrez-Cervello, G., Eds., Water Purification and Management, Springer Science-Business Media BV, Algiers, 95-117. https://doi.org/10.1007/978-90-481-9775-0_3

[218]Weber, W.J. and Morris, J.C. (1963) Kinetics of Adsorption on Carbon from Solutions. Journal of the Sanitary Engineering Division, American Society of Civil Engineers, 89, 31-60. 
[219]Tan, I.A.W. and Hameed, B. (2010) Adsorption Isotherms, Kinetics, Thermodynamics and Desorption Studies of Basic Dye on Activated Carbon Derived from Oil Palm Empty Fruit Bunch. Journal of Applied Sciences, 10, 2565-2571. https://doi.org/10.3923/jas.2010.2565.2571

[220]Walker, G.M., Hansen, L., Hanna, J.A. and Allen, S.J. (2003) Kinetics of a Reactive Dye Adsorption onto Dolomitic Sorbents. Water Research, 37, 2081-2089. https://doi.org/10.1016/S0043-1354(02)00540-7

[221] Abdel-Ghani, N.T., El-Chaghaby, G.A. and Zahran, E.M. (2015) Pentachlorophenol (PCP) Adsorption from Aqueous Solution by Activated Carbons Prepared from Corn Wastes. International Journal of Environmental Science and Technology, 12, 211-222. https://doi.org/10.1007/s13762-013-0447-1

[222]Diagboya, P.N., Olu-Owolabi, B.I. and Adebowale, K.O. (2014) Microscale Scavenging of Pentachlorophenol in Water Using Amine and Tripolyphosphate-Grafted SBA-15 Silica: Batch and Modeling Studies. Journal of Environmental Management, 146, 42-49. https://doi.org/10.1016/j.jenvman.2014.04.038

[223]Suteu, D. and Malutan, T. (2013) Industrial Cellolignin Waste as Adsorbent for Methylene Blue Dye from Aqueous Solutions. Bioresource, 8, 427-446.

[224]Nethaji, S., Sivasamy, A. and Mandal, A.B. (2013) Adsorption Isotherms, Kinetics and Mechanism for the Adsorption of Cationic and Anionic Dyes onto Carbonaceous Particles Prepared from Juglans regia Shell Biomass. International Journal of Environmental Science and Technology, 10, 231-242. https://doi.org/10.1007/s13762-012-0112-0

[225]Song, S.T., Saman, N., Johari, K. and Mat, H. (2013) Removal of Hg (II) from Aqueous Solution by Adsorption Using Rawand Chemically Modified Rice Straw as Novel Adsorbents. Industrial \& Engineering Chemistry Research, 52, 13092-13101. https://doi.org/10.1021/ie400605a

[226]Li, K., Cao, J., Li, H., Liu, J., Lu, M. and Tang, D. (2016) Nitrogen Functionalized Hierarchical Microporous/Mesoporous Carbon with a High Surface Area and Controllable Nitrogen Content for Enhanced Lead (II) Adsorption. Royal Society of Chemistry, 6, 92186-92196.

[227]Uslu, G. and Tanyol, M. (2006) Equilibrium and Thermodynamic Parameters of Single and Binary Mixture Biosorption of Lead (II) and Copper (II) Ions onto Pseudomonas Putida: Effect of Temperature. Journal of Hazardous Materials, 135, 87-93. https://doi.org/10.1016/j.jhazmat.2005.11.029

[228]Khan, M.A., Kim, S., Rao, R.A.K., Abou-Shanaba, R.A.I., Bhatnagar, A., Song, H., and Jeon, B.H. (2010) Adsorption Studies of Dichloromethane on Some Commercially Available GACs: Effect of Kinetics, Thermodynamics and Competitive Ions. Journal of Hazardous Materials, 178, 963-972. https://doi.org/10.1016/j.jhazmat.2010.02.032

[229]Gorzin, F. and Bahri-Rasht, A.M.M. (2017) Adsorption of Cr (VI) from Aqueous Solution by Adsorbent Prepared from Paper Mill Sludge: Kinetics and Thermodynamics Studies. Adsorption Science and Technology, 1-21. https://doi.org/10.1177/0263617416686976

[230]Nollet, H., Roels, M., Lutgen, P., Van, M.P. and Verstraete, W. (2003) Removal of PCBs from Wastewater Using Fly Ash. Chemosphere, 53, 655-665. https://doi.org/10.1016/S0045-6535(03)00517-4

[231]Xiong, C. (2010) Adsorption of Cadmium (II) by Chitin. Journal of the Chemical Society of Pakistan, 32, 429-435.

[232]Ruthven, D.M. (1984) Principles of Adsorption and Adsorption Processes. John Wiley and Sons, New York. 
[233] Srivastava, N.C. and Eames, I.M. (1998) A Review of Adsorbents and Adsorbates in Solid-Vapour Adsorption Heat Pump Systems. Applied Thermal Engineering, 18, 707-714. https://doi.org/10.1016/S1359-4311(97)00106-3

[234]Denizli, A., Say, R. and Arica, Y. (2000) Removal of Heavy Metal Ions from Aquatic Solutions by Membrane Chromatography. Separation and Purification Technology, 21, 181-190. https://doi.org/10.1016/S1383-5866(00)00203-3

[235]Al-Anber, M.A. (2011) Thermodynamics Approach in the Adsorption of Heavy Metals. In: Moreno-Pirajan, J.C., Ed., Thermodynamics-Interaction Studies-Solids, Liquids and Gases, InTech, Rijeka, 737-764.

Submit or recommend next manuscript to SCIRP and we will provide best service for you:

Accepting pre-submission inquiries through Email, Facebook, LinkedIn, Twitter, etc. A wide selection of journals (inclusive of 9 subjects, more than 200 journals) Providing 24-hour high-quality service User-friendly online submission system Fair and swift peer-review system Efficient typesetting and proofreading procedure Display of the result of downloads and visits, as well as the number of cited articles Maximum dissemination of your research work

Submit your manuscript at: http://papersubmission.scirp.org/ Or contact gep@scirp.org 